\section{Practices and Attitudes of}

\section{Women Regarding Family}

\section{Planning And Menstrual}

Regulation in The Sylhet

Division of Bangladesh

\section{SM Zahedul Islam Chowdhury*}

Research Fellow, Bangladesh Institute of Development Studies (BIDS), E-17, Agargaon, Sher-e-Bangla

Nagar, Dhaka-1207, Bangladesh
Received: 21 April, 2020

Accepted: 20 May, 2020

Published: 21 May, 2020

*Corresponding author: Dr. S.M. Zahedul Islam Chowdhury, Research Fellow, Bangladesh Institute of Development Studies (BIDS), E-17, Agargaon, Sher-eBangla Nagar, Dhaka-1207, Bangladesh, E-mail: zahed@bids.org.bd

Keywords: Menstrual regulation; Family planning; Unwanted pregnency

https://www.peertechz.com

Check for updates

\begin{abstract}
Several hundred thousand women in Bangladesh terminate their pregnancy either by menstrual regulation (MR) or through abortion. Government policy does not recognize abortion; but there exists a policy for MR, permitting termination of unwanted pregnancy up to 10 weeks from the last menstrual period. But access to safe MR is limited-unskilled and untrained providers mostly conduct termination of pregnancy; making unsafe abortion one of the leading causes of maternal deaths in Bangladesh. In order to reduce maternal mortality and morbidity in the country, some initiative was launched.The overall aim was to improve knowledge of and access to quality MR services for the prevention of unsafe abortion and unsafe MR. The present study will examine the impact of the MR intervention, i.e. how far the program has been successful in increasing awareness regarding timeline for safe MR. Findings suggest that overall respondents in the intervention area are much better off in terms of awareness regarding timeline of safe MR ( $79 \%$ of women) compared to their control group counterparts (51\%), People belonging to different age groups (adolescents, adults, the aged) and socio economic categories (rich/poor, educated/illiterate) get the relevant message regarding WHY, WHEN, WHERE, and by WHOM the MR procedure should be performed. The implementing agencies have played a crucial role in promoting safe MR in their respective working areas in the aspects of awareness creation, standard guideline on MR, enabling environment, and rights based approach. However, there still remains scope to improve quality of care.
\end{abstract}

\section{Introduction}

Menstrual regulation (MR) is defined as "An interim method of establishing non- pregnancy for a woman who is at risk of being pregnant, whether or not she is pregnant in fact" [1-3]. On the other hand, Abortion is defined as the interruption or termination of pregnancy after the implantation of the blast cyst in the endometrium and before the resulting fetus has attained viability. Induced abortions are caused by deliberate interference, initiated voluntarily with the intention to terminate a pregnancy; all other abortions are called spontaneous abortion [4].
Bangladesh is unique in South Asia in making menstrual regulation (MR) services available to women at the community level. Menstrual regulation involves evacuation of the uterus by vacuum aspiration within 6-10 weeks of a missed menstrual period. Although abortion is prohibited in Bangladesh except to save a woman's life (derived from the Penal Code of India 1860 and the British Offences against the Person Act 1861), menstrual regulation is not prohibited as it is considered to be an "interim method to establish a state of non-pregnancy in a woman who is at risk of being pregnant". Hence, it is usually done without a pregnancy test. Under the Bangladesh Penal Code of 1860 , abortion is permissible only to save the life of a 
woman. In all other circumstances, abortion-self-induced or otherwise-is a criminal offense punishable by imprisonment, fines or both. Menstrual regulation(MR) - officially recognized as an interim method for establishing non-pregnancy-has been available free of charge in the government's family planning program as a public health measure since 1979 [5].

One of the important goals of Health, Nutriton and Population Sector Programme (HNPSP) of the government of Bangladesh has been to improve the health and family welfare status of the most vulnerable groups- women, children and the poor. Bangladesh has achieved significant progress in health and population indicators over the last few years (due to increased access to health and FP services) through a combination of facility level, community and household level service provision strategies. The fertility transition is already underway in the country and the success of the immunization program is most impressive, including reductions in infant and child mortality. The contraceptive prevalence rate has already reached more than $50 \%$ level. On an average, women in Bangladesh now give birth to only 2.3 children as compared to 6.3 children in the mid 1970s. More than 50 per cent of married couples of reproductive age have been protected by modern contraception now as compared to only 8 per cent in the early seventies. The expectation of life at birth for both sexes has increased from about 45 years in the mid 1970 s to 66.7 years in 2008. These are some of the notable changes that have occurred in the demographic profile of Bangladesh. It is remarkable that despite adverse socio-economic environment, commendable success in reproductive and child health has been achieved over the period of three decades. The infant mortality rate showed a steady decline from 150 deaths per 1000 live births in 1973 to 94 in 1991, 47 by 2007 [6] and 43 in 2011 [7], while the under five-mortality rate declined from around 260 deaths per 1000 live births to only 53 over the same period [7]. Immunization coverage at the age of 12 months increased from as low as $54 \%$ in 1990 to $82.5 \%$ in 2011 and the country is expecting to attain polio-free status very soon [8].

\section{Objectives}

The main purpose of the present impact study is to assess whether and to what extent the interventions of the implementing agencies (i.e. MSCS/FPAB) have had an impact in terms of increasing awareness regarding MR among women and in increasing knowledge on safe timeline and appropriate place for performing MR and to what extent has the intervention been effective in increasing the social awareness regarding MR and abortion issues and removing misconceptions related to MR. Significance of the study is to identify some problems/ issues of women regarding MR which will help for further policy implementation. The rest of the paper is organized as follows. Section 3 provides literature review, section 4 provides methodology, section 5 describes knowledge and attitudes of women regarding FP and MR and section 6 will discuss results and findings.

\section{Literature review}

\section{Status of Maternal Mortality}

There are two indicators for monitoring the reduction of maternal mortality - maternal mortality ratio and proportion of births attended by skilled health personnel. In 2006 the estimated MMR of Bangladesh was 290 (UNFPA), but according to BBS, the MMR is 315 for 2007 estimated from the Sample Vital Registration System . According to government statistics, maternal deaths fell by at least $60 \%$ from 1990 to $2010-2011$ [9]. Further evidence in this regard comes from the two official government studies of maternal mortality (Bangladesh Maternal Mortality Surveys, or BMMS), which were conducted in 2001 and 2010. Their findings offer further evidence of this steep decline: a drop in maternal mortality of two-fifths in less than one decade. In 2011, MMR was 194. Maternal mortality has declined considerably in Bangladesh over the past few decades. Some of that decline-though precisely how much cannot be quantified - is likely attributable to the country's menstrual regulation (MR) program, which allows women to establish non-pregnancy safely after a missed period and thus avoid recourse to unsafe abortion [10]. According to Hossain, et al. [10]. Bangladesh has succeeded in reducing deaths during pregnancy and childbirth by improving access to maternal health care and lowering fertility, especially births that pose above-average health risks (e.g., births occurring to highparity women). What makes the country unique, however, is the potential contribution of an authorized procedure-known as menstrual regulation, or MR - to "establish non- pregnancy" after a missed period [2]. A national level survey conducted during 1978-79 found that complications from unsafe abortion played a major role in $26 \%$ of maternal deaths [11]. Similarly, a study of rural areas conducted during the 1980s found that the proportion of maternal deaths attributable to abortion was $15 \%$ [12]. However, there has been substantial improvement in this regard over the last two decades as will be clear from the following. Findings from first national maternal mortality survey of 2001 [13], found a substantially lower proportion of maternal deaths attributable to abortion-only $5 \%$ of maternal deaths were related to induced abortion [14]. The 2011 BMMS found an even smaller percentage, merely 1\% of maternal deaths were attributable to abortion during 20082010. If this last estimate is accurate, it points to a steep decline in the proportion of maternal deaths due to unsafe abortion [7]. However, it needs to be emphasized that the various surveys used different methodologies, some methodologies were less rigorous than others. Again, surveys related to maternal mortality in general, and of abortion related mortality in particular, are likely to suffer from recall lapse and high levels of under-reporting [9].

It is to note that Bangladesh is a moderate Muslim country with some cultural values of conservative nature. Living together with partner, extramarital sex and getting children without being married is against the norm of the society Such women are socially excluded and their children cannot be reared as other children in the society. Women therefore try to hide their relationship with their partner, and in case of pregnancy outside wedlock, they try to abort the child in secrecy. In this backdrop, MR is considered as a tool to hide the 'sin' of secret sexual relations, and therefore is socially unacceptable in Bangladesh. MR is also considered as a sin from religious point of view. 'Children' are considered to be 
'gift of God' and any harm to them is not religiously acceptable. Moreover, there remains some misconception about the health hazards associated with MR, which makes it unpopular among general people. Social, cultural and religious norms along with some misconception make MR a sensitive issue in Bangladesh.

\section{The marie stopes clinic society (MSCS)}

The Marie Stopes Clinic Society has been providing a wide range of Sexual and Reproductive Health (SRH) services including MR in Bangladesh since 1988. Under the Embassy of the Kingdom of the Netherlands (EKN) support, the following districts have been covered: Narayangonj of Dhaka division; Maulvibazar of Sylhet division; Feni under Chittagong division, and Sherpur under Dhaka division. The main purpose of MSCS was to increase awareness on prevention of unwanted pregnancy and MR services and to improve quality of safe MR services. The community awareness strategy used by MSCS involved different sectors of the community: NGO field workers, male key decision makers, locally elected male and female leaders, female community support groups (FCSG), micro-credit NGO field workers, college and school teachers, and the DDFP.

\section{The Family Planning Association of Bangladesh (FPAB)}

The Family Planning Association of Bangladesh is a member of the International Planned Parenthood Federation (IPPF) and has been working in Bangladesh since 1953. It is the oldest NGO in Bangladesh and provides a range of reproductive health, family planning services, including MR services. The project has been implemented at six FPAB clinics in six districts: Barisal, Chittagong, Sylhet, Jhalakati, Magura and Netrokona. In order to promote community awareness, Reproductive Health Promoters (RHP) have been used to disseminate the key messages to the community. The organization has carried out a base- and end-line KAP surveys in all project locations, including the Sylhet division.

\section{The Menstrual Regulation (MR) program in bangladesh}

The unique contribution of MR to women's health care in Bangladesh dates from the early 1970s. During the early 1970s, the government of Bangladesh introduced MR services in a few urban family planning clinics and district hospitals under the guidance of an expert team from Bangladesh, India, the United Kingdom, and the United States [15,16]. In 1978, the Pathfinder Fund initiated and funded the Menstrual Regulation Training and Service Programs (MRTSP) in seven government medical colleges located throughout the country, two district hospitals, and one family planning clinic. This was the start of what was to become the Menstrual Regulation Training and Services Program (MRTSP). MR services were introduced in Bangladesh in 1974 on a small scale to assess the feasibility of providing them nationally; in 1979, a training program was initiated in seven medical college hospitals and two district hospitals [17]. In 1979 MR was legalized and incorporated into the National Family Planning Program. The government stated unequivocally that MR services were to be available in all government hospitals and health and family planning complexes at the district and upazila levels. In order to promote this program the government issued a circular including MR in the national family planning program and encouraging service providers to offer service in all government hospitals and health and family planning complexes (the present day UHCs) [18]. The program was designed to train government doctors, a few private doctors, and female family planning workers (Family Welfare Visitors, or FWVs, employed at upazila/union level health posts) in MR techniques. Menstrual regulation (MR) is widely available in Bangladesh through public, NGO and private sector facilities, even though abortion is illegal except to save a woman's life. For more than two decades, the MR programme was run as a vertical programme. However, in1998the Government of Bangladesh introduced the Health and Population Sector Programme (HPSP) incorporating menstrual regulation into the essential services package (ESP).

MR is allowed up to 10 weeks after the last menstrual period (LMP) if performed by a physician [19]. Family welfare visitors (FWVs) and paramedics such as sub- assistant community medical officers (SACMOs) are permitted to provide MR services up to eight weeks after the LMP. The predominantly female FWVs have a minimum of 10 years of schooling and receive at least 18 months' training in reproductive and child health services, including training in how to perform MRs [20]. If MRs were universally accessible in Bangladesh, they could greatly reduce the potential need for women to have an unsafe clandestine abortion. Currently, a lot of women who would like to get an MR face barriers to obtaining one; many of them resort to unsafe abortion as a result. Because induced abortions are legally restricted in Bangladesh, they are often practiced clandestinely in unhygienic settings, performed by untrained providers, or both. By averting unsafe abortions and their associated health complications, MR could have a positive impact on women's health and survival [10].

\section{Menstrual regulation (MR) Services}

The original impetus for introducing MR services came from scientists, government and international leadership. Support for provision of this reproductive health service is broad based and includes these as well as other stake-holders such as service providers and women's rights organizations [15]. Nevertheless, studies have suggested that there is room and need for improvement in access to quality MR services. In addition, a recent review of the MR program has argued that it has been marginalized within overall health policy in Bangladesh over the last decade [20]. A government authorization rule regulates MR [2], which is generally performed with manual vacuum aspiration (MVA). The rule gives specific guidance for the provision of MR services, covering the types of providers who can offer the service, namely, doctors, family welfare visitors (FWVs) and paramedics (include providers such as SACMO, and medical assistants); the context of service provision, either outpatient or inpatient; and the maximum number of weeks permitted since the last menstrual period (LMP). Although MR is allowed up to eight weeks after LMP when performed by FWVs and paramedics, and up to10 weeks after LMP when performed by a physician, providers sometimes perform the procedure later as well [21-27]. 
Currently MR is widely practiced throughout the country and is available at all tiers, from district and higher level hospitals down to union (consisting of 15-20 villages) level health centres. It is also available in a limited number of NGO clinics and in the private sector. Both doctors and paramedics provide MR, but at the union level, female paramedics are the only trained providers. Maternal health services in Bangladesh are provided at community and facility levels through a national network of public-sector facilities, ranging from Union Health and Family Welfare Centres (UH\&FWCs), which are rural clinics staffed by FWVs and paramedics, to larger clinics called Mother and Child Welfare Centres (MCWCs) and Upazila Health Complexes (UHCs), and district hospitals. FWVs are important actors in the provision of MR services, especially in rural areas. At the community level, female family welfare assistants (FWAs) mainly provide family planning services and some maternal health services to rural women.

\section{Data and methodology}

\section{Study design}

The present study was limited to project areas of Family Planning Association of Bangladesh (FPAB) and Marie Stopes Clinic Society (MSCS) being implemented in North-east region i.e. Sylhet division - FPAB in Sylhet district and MSCS in Maulvibazar district. The catchment area of the FPAB project in Sylhet district is the peri-urban area of the city of Sylhet and the surrounding rural areas (covering Sylhet Sadar Upazila and South Surma Upazila), while the catchment area of the Marie Stopes project in Maulvibazar is the whole of Maulvibaza district. Two upazilas from Sylhet and from Maulvibazar each were covered, which are considered as 'intervention' area. For comparison purposes, two upazilas from Habigonj district were selected as 'control area'.

\section{Selection of respondents for household survey}

The household survey covered 400 households in project/ intervention area and 200 households in control area. From each district, a total of 200 households were selected as follows. For the intervention area in Sylhet Sadar upazila and South Surma upazila, two unions (rural area) and two wards (covering peri-urban areas) were selected at random. From each selected union/ward, two villages/mohallas were selected. Finally, 50 households from each village/mohalla were selected at random. This gave a total of 200 households from Sylhet Sadar and Surma upazila (FPAB area). Similarly two upazilas from each of Maulvibazar (MSCS area) and Habigonj district (Control group) were selected .In this way, a total of 600 households from the three districts were selected-400 from intervention area and 200 from control area. Finally, from each household, one currently married woman (aged 1549 years) was selected for interview. In each household, the women aged 15-49 were asked to respond on questions related to reproductive health, and in particular, on (long term) family planning methods and on the knowledge and practice concerning safe MR.
In addition, as male of household heads are assumed to have an important role in the decision making, information was also obtained from male-heads to have an idea about the role of men and their influence on pregnancy termination through MR. In most of Bangladesh, the family is mainly patriarchal, patrilocal and patrilineal and the South Asia region is well known for the kinds of in-egalitarian gender relations that are related with gender discrimination. In view of the above, the present study has covered 300 male-heads of household from three districts-Sylhet, Maulvibazar and Habigonj-taking 100 from each district. From each sample village/mohalla, 25 male-heads were selected randomly. Thus, there were a total of 300 male household heads from the three districts-200 from intervention area and 100 from control area. A pretested structured questionnaire was applied to obtain relevant information for both women and male household head.

\section{Qualitative data collection methods}

The study also examined the role of service providers to assess their knowledge on job responsibility, opinions on the quality of MR services, extent of follow-up services and so on. In-depth interviews were conducted with managers in health facilities and health care providers at different levels. Key Informant Interview (KII) of program managers included: Civil Surgeons at the district hospital (DH) and program managers/project directors of FPAB/MSCS, Upazila Health and Family Planning Officer (UHFPO) at the Upazila Health Complex (UHC), Sub-Assistant Community Medical Officer (SACMO) at the UHFWC etc; while interview of service providers included: doctors, nurses and health assistants/ FWVs/FWAs working at the health facilities in study locations. Information was obtained on constraints regarding hospital management and improving efficiency of service delivery, and other related aspects of quality of care. Guidelines were prepared for KIIs.

\section{Knowledge and attitudes Of women regarding family planning (Fp) and menstrual regulation}

Socio-economic profile of the women respondents: As already mentioned in the methodology section, a total of 600 women aged 15-49 years-200 each from Sylhet, Maulvibazar and Habigonj-were covered by the present survey. The survey has collected information regarding age, level of education, occupation, family income, reproductive health, and on the knowledge, attitude and practice concerning family planning and MR. Sylhet and Maulvibazar districts are considered as 'intervention' (program) area and Habigonj district as 'control area'. As far as the age of the women is concerned, most of the women belong to the age group20 -29 years -around $60 \%$ in Sylhet, 50\% in Maulvibazar and 56\% in Habigonj. About 11 percent of the respondents belong to the 15-19 year age group in Sylhet and Maulvibazar compared to 7 percent in Habigonj. The age distribution of women in the study area was more or less similar-the mean age was 28.34 years in Sylhet, 29.30 years in Maulvibazar and 28.85 years in Habigonj. Distribution of the respondents by educational level shows that there is some difference in the literacy level of women in the intervention and control area. About a quarter of the respondents in Sylhet 
(27\%) and Maulvibazar (26\%) were illiterate compared to only $13 \%$ in Habigonj. The distribution of the women by their occupation in all three sample areas is almost similar. For example, an overwhelming proportion of respondents reported them as housewives- $91.5 \%$ in Sylhet, $93.5 \%$ in Maulvibazar and $95 \%$ in Habigonj. In terms of monthly household income, The average monthly household income was lowest in Sylhet Tk. 12,240 followed by Tk. 13,293 in Maulvibazar and Tk. 13,473 in Habigonj. On the other hand, per capita monthly income was highest in Sylhet Tk. 2,915 compared to Tk. 2,684 and Tk.2,654 in Maulvibazar and Habigonj respectively.

\section{Profile of the male household heads}

As mentioned in the methodology section, the present study has covered 300 male-heads of household from three districts - Sylhet, Maulvibazar and Habigonj-taking 100 from each district. In the survey area, most ( $54 \%$ on average) of the male household heads are in the age group of 25 to 34 years (55\% in Sylhet, 50\% in Maulvibazar and 58\% in Habigonj). In terms of literacy and education, most of the respondents were illiterate or with no formal schooling. The rate of illiteracy was higher in the intervention area compared to control area $(47.5 \%$ vs $18 \%$ ). In terms of literacy and education, the situation was worse in intervention area. The distribution of household heads by principal occupation shows that the predominant occupation is small business/ petty trading (28.7\%) or nonagricultural wage labour (19\%). Overall, average monthly income of the household heads from all sources was Tk.12995 per month. However, mean monthly income of households in the intervention area was somewhat higher in the intervention area (Tk. 13167 in Sylhet and Tk.14240 in Maulvibazar) than that of the control area (Tk.11579).

\section{Health seeking behaviour of the women respondents}

The respondents were asked about the places where they usually visit for treatment during sickness. In case of a mild illness, a person may use family based practices only, or buy some drugs from the pharmacy or consult unqualified practitioners. In case of service or long lasting illness, s/he may consider using either professional or lay care remedies, or both of them. In Sylhet, $84.5 \%$ of the respondents mentioned that they generally go to the district hospital for the treatment of household members during sickness, while $60 \%$ and $65 \%$ go to the UHC and FWC respectively for treatment purposes. However, $33.5 \%$ of the respondents mentioned that they consult MBBS doctor, while another $21.5 \%$ goes to the village doctor/ medicine seller as their preferred place of treatment in case of sickness. The health seeking behavior in the other intervention area (Maulvibazar) was more or less similar. By contrast, the pattern in the control area is such that a majority of the households $(62 \%)$ consult unqualified doctors/traditional practitioners/medicine sellers for treatment purposes, about a quarter of them also go for homeopathy treatment. Compared to the intervention area, lesser number of households from control area visits public health facilities (DH, UHC and FWC) for treatment purposes (ranging between 28.5 to $42.5 \%$ ) (Table $1)$.

\section{Marriage and reproductive health of the women respon- dents}

Age at marriage: Respondents were asked about their age at first marriage. According to data as presented in Table 2, about a fifth of the women in Sylhet (19\%) and Maulvibazar $(18.5 \%)$ were married by age 14 , the corresponding figure for Habigonj was $14 \%$. Similarly, $31 \%$ of women in Sylhet, $34 \%$ in Maulvibazar and 27.5\% in Habigonj were married by age 15 .

The findings show that an overwhelming proportion of women in the sample areas (58\% in Sylhet, $66 \%$ in Maulvibazar and $54 \%$ in Habigonj) were married before they were 18 years of age (i.e. before the legal minimum age at marriage for girls). This implies that more than half of the marriages in the study areas were, in fact, child marriages, which is forbidden by law. The average age at first marriage is found to be $16.95,16.76$ and 17.13 years in Sylhet, Maulvibazar and Habigonj respectively.

Table 1: Distribution of the Women Respondents According to their Usual Place of Treatment during Sickness: By area.

\begin{tabular}{|c|c|c|c|c|}
\hline \multirow{2}{*}{ Type of Facility } & \multicolumn{3}{|c|}{ Intervention Areas } & Control Area \\
\cline { 2 - 5 } & Sylhet & Maulvibazar & Both & Habigonj \\
\hline District Hospital & 84.5 & 53.0 & 68.75 & 39.5 \\
\hline UHC & 60.0 & 71.0 & 65.5 & 42.5 \\
\hline FWC & 65.0 & 63.5 & 64.25 & 28.5 \\
\hline MBBS doctor/private chamber & 33.5 & 20.0 & 26.75 & 18.5 \\
\hline NGO/private clinic & 15.0 & 11.0 & 13 & 11.5 \\
\hline Unqualified allopath/Village & & & & \\
\hline doctor/ & 24.0 & 25.5 & 24.75 & 62.0 \\
\hline medicine seller & & & & \\
\hline Homeopath & 10.5 & 38.0 & 24.25 & 28.0 \\
\hline Kobiraj/Hekim & 4.0 & 15.5 & 9.75 & 8.0 \\
\hline Spiritual Healer & 1.5 & 2.5 & 2 & - \\
\hline Self Medication & - & 1.0 & 0.5 & - \\
\hline Don't go any where & - & - & - & - \\
\hline
\end{tabular}

\section{Consequences of early marriage}

Historically, Bangladeshi women are married early. The 1979 convention on the "Elimination of All Forms of Discrimination Against Women", and the 1990 African Charter on the "Rights and Welfare of the Child" suggest a minimum age of marriage of 18 years (for girls), consistent with the definition of childhood articulated in the 'Convention on the Rights of the Child'. Accordingly, the minimum age at marriage for girls in Bangladesh is 18 years and any marriage of girls below 18 years is illegal. Women who marry young tend to have less education and begin childbearing earlier and have less decision making power in the household. Consequently, women who marry early become mother at an early age and are more likely to experience higher morbidity and mortality compared to those who marry after their teens.

\section{Number of children born alive and living children}

Respondents were also asked about the number of children born alive and currently living. It is evident from Table 3 that in Sylhet, the average number of children born alive per woman and currently living are 2.58 and 2.29 respectively. Similarly, in 
Maulvibazar the mean number of children born alive is 2.62 and number of children currently alive is 2.32 , while in Habigonj the corresponding figures are 2.78 and 2.51 respectively. The data shows that mean number of children born alive and currently living is slightly higher in Habiganj compared to the intervention area (Tables 2,3).

Regarding the last pregnancy, respondents were asked about the way how the decision of being pregnant was taken-whether husband-wife decided mutually, or it was due to contraception failure. An overwhelming proportion of women (ranging between 70 to $87 \%$ ) mentioned that decision was made by mutual understanding of the couple (Table 4). However, about a quarter of the women in intervention area (23.85) maintained that pregnancy occurred due to failure of FP method $(7.75 \%)$, or it was unplanned pregnancy $(14.6 \%)$. The corresponding figure was $10.7 \%$ in Control (Habigonj) area. An insignificant proportion of women said that pregnancy occurred due to husband's own decision in both areas.

\section{Family planning}

Knowledge and awareness about family planning methods: Information on knowledge of family planning was obtained by asking women whether they have ever heard of family planning method. It is evident that knowledge about family planning is universal-100 percent respondents in both the intervention and control areas possess this knowledge. Knowledge was also assessed for different methods of family planning (Pill, condom, injection, IUD, Implant/Norplant, ligation, vasectomy, Azol/ withdrawal, safe period etc.) (Table 5).

It may be mentioned that Bangladesh has achieved a remarkable progress in raising the contraceptive prevalence rate from less than 8 per cent in 1975 to about 56 per cent in 2007- a seven-fold increase over a period of three decades. The steady increase in the use of contraception has been the major determinant of fertility decline in Bangladesh.

\section{Advantages and disadvantages of family planning methods}

The respondents were asked about their perceptions regarding advantages/demerits of FP methods. About 90.5 percent of respondents in intervention area stated about 'solvency of the family', followed by'easier to provide

\begin{tabular}{|c|c|c|c|c|}
\hline \multirow[b]{2}{*}{$\begin{array}{c}\text { Age at first marriage } \\
\text { (years) }\end{array}$} & \multicolumn{3}{|c|}{ Intervention Areas } & \multirow{2}{*}{$\begin{array}{l}\text { Control Area } \\
\text { Habigonj } \\
(\mathrm{N}=200)\end{array}$} \\
\hline & $\begin{array}{l}\text { Sylhet } \\
(\mathrm{N}=200)\end{array}$ & $\begin{array}{l}\text { Maulvibazar } \\
(\mathrm{N}=\mathbf{2 0 0})\end{array}$ & Both & \\
\hline Up to 12 & 4.5 & 1.5 & 3 & 0.5 \\
\hline 13 & 7.0 & 9.0 & 8 & 7.0 \\
\hline 14 & 8.5 & 8.0 & 8.25 & 6.5 \\
\hline 15 & 12.0 & 15.5 & 13.75 & 13.5 \\
\hline 16 & 14.5 & 17.5 & 16 & 13.5 \\
\hline 17 & 11.5 & 14.0 & 12.75 & 12.5 \\
\hline 18 & 17.0 & 14.0 & 15.5 & 20.5 \\
\hline 19 & 7.0 & 6.0 & 6.5 & 10.5 \\
\hline $20+$ & 18.0 & 14.5 & 16.25 & 15.5 \\
\hline $\begin{array}{c}\text { Mean age at } \\
\text { Marriage }\end{array}$ & 16.95 & 16.75 & 16.85 & 17.13 \\
\hline
\end{tabular}

Table 3: Number of Children Born Alive and Currently Living by Area

\begin{tabular}{|c|c|c|c|}
\hline \multicolumn{4}{|c|}{ Intervention Areas } \\
\hline & Rural & Urban & Total \\
\hline \multicolumn{4}{|c|}{ Sylhet } \\
\hline Children born alive & 2.66 & 2.50 & 2.58 \\
\hline Children currently living & 2.33 & 2.25 & 2.29 \\
\hline \multicolumn{4}{|c|}{ Maulvibazar } \\
\hline Children born alive & 2.66 & 2.57 & 2.62 \\
\hline Children currently living & 2.41 & 2.23 & 2.32 \\
\hline \multicolumn{4}{|c|}{ Intervention (Mean) } \\
\hline Children born alive & 2.66 & 2.54 & 2.6 \\
\hline Children currently living & 2.37 & 2.24 & 2.31 \\
\hline \multicolumn{4}{|c|}{$\begin{array}{c}\text { Control Area } \\
\text { (Habigonj) }\end{array}$} \\
\hline Children born alive & 2.99 & 2.56 & 2.78 \\
\hline Children currently living & 2.61 & 2.40 & 2.51 \\
\hline
\end{tabular}

Table 4: Decision regarding Last Pregnancy.

\begin{tabular}{|c|c|c|c|c|}
\hline \multirow{2}{*}{ Indicators } & \multicolumn{3}{|c|}{ Intervention Areas } & Control Area \\
\cline { 2 - 5 } & Sylhet & Maulvibazar & Both & Habigonj \\
\hline $\begin{array}{c}\text { Mutual understanding of the } \\
\text { couple }\end{array}$ & 70.0 & 75.3 & 72.65 & 87.2 \\
\hline $\begin{array}{c}\text { Husband's own decision/ } \\
\text { Compelled by }\end{array}$ & 3.5 & 2.5 & 3 & 0.5 \\
\hline $\begin{array}{c}\text { husband } \\
\text { Unplanned }\end{array}$ & 12.5 & 16.7 & 14.6 & 2.0 \\
\hline Lack of FP methods & 1.0 & 2.0 & 1.5 & 3.6 \\
\hline Unwanted/failure of FP method & 13.0 & 2.5 & 7.75 & 5.1 \\
\hline Other & 0 & 1.0 & 0.5 & 1.5 \\
\hline
\end{tabular}

Table 5: Percentage Distribution of Women Who Have Heard About FP Methods: By Area

\begin{tabular}{|c|c|c|c|c|}
\hline \multirow{2}{*}{$\begin{array}{c}\text { Knowledge } \\
\text { about } \\
\text { FP methods }\end{array}$} & Sylhet & Maulvibazar & Total & Habigonj \\
\cline { 2 - 5 } & 100.0 & 100.0 & 200 & 100.0 \\
\hline Yes & 0.0 & 0.0 & 0 & 0.0 \\
\hline No & 200 & 200 & 400 & 200 \\
\hline N & & & & \\
\hline
\end{tabular}

education for children' (maintained by 70.5\%), 'mother's health and nutrition is ensured' (reported by $69.5 \%$ ), and 'better health and nutrition of children' (mentioned by $60.25 \%$ ) . Regarding disadvantages of FP methods, the various responses included "side effects" (ranging between 72 to 94\%), "risk of infertility" (ranging between 35 to 70\%), "husband does not like" (ranging between 26 to $49 \%$ ), etc (Tables 6,7 ).

\section{Consequences of frequent pregnancies}

Respondents were also asked about their opinion regarding consequences of large family and frequent pregnancies. Regarding adverse consequences of repeated pregnancies, $96.25 \%$ espondents of intervention area mentioned about poor health of mother and children, followed by financial burden $(89.75 \%)$, and inadequate birth spacing (62.75\%). Similar observations were also made about adverse consequences. However, more than a half of the respondents in control area $(58 \%)$ mentioned about positive aspects of frequent pregnancies - i.e. the benefits of a large family, compared to 
one-fourth of the respondents in the intervention area who mentioned about benefits of large family (Table 8).

\section{Knowledge on different family planning methods}

The respondents were asked to mention some of the specific family planning methods they know about. It is evident that pill, condom, injection and female sterilization is almost universally known (more than $90 \%$ in the study area), while knowledge of other methods like IUD, implant/ norplant, vasectomy varies between 70 percent to 90 percent. By contrast, knowledge of traditional methods like safe period, Azol/withdrawal ranges between 23 percent and 68 percent. Surprisingly, regarding emergency pill very few women possess this knowledge-only 15.75 percent women in intervention area compared to 5.5 percent in control area ever heard of emergency pill Figure 1 Table 9.

\section{Current use of family planning methods}

Family planning plays a crucial role in safeguarding the health of women, particularly in a developing country like Bangladesh where they are often forced to carry an unplanned and unwanted pregnancy. With respect to current use of contraception, it is evident from the findings (Tables 10,11) that between 59 to 75 percent of the unmarried women in the intervention area are currently using any family planning method (the figure of current use is $\mathbf{1 6 . 5}$ percent higher in Sylhet than in Maulvibazar). By contrast two-thirds (66\%) of control group women $(66.75 \%)$ are current users of any family planning method. The method-mix of current users ranges between 56 to 72 percent for pill and 10 to 20 percent for injection in both the intervention and control area. However, pill users were higher $(72 \%)$ in the control area than in the intervention area $(58 \%)$, while use of injection was lower $(9.8 \%)$ in control than in intervention area (19.4\%). Surprisingly, 12 percent of the current users in control area are still using traditional methods (safe periods, withdrawal) where failure rate may

Table 6: Percentage Distribution of Respondents by Their Perception about Advantages of FP Methods: by area (Multiple Responses).

\begin{tabular}{|c|c|c|c|c|}
\hline \multirow{2}{*}{ Advantages of FP methods } & \multicolumn{3}{|c|}{ Intervention Areas } & Control Area \\
\cline { 2 - 5 } & Sylhet & Maulvibazar & Both & Habigonj \\
\hline Solvency of the family increases & 91.0 & 90.0 & 90.5 & 70.5 \\
\hline $\begin{array}{c}\text { Easier to provide children with } \\
\text { education }\end{array}$ & 61.5 & 79.5 & 70.5 & 89.5 \\
\hline $\begin{array}{c}\text { Children have better health and } \\
\text { nutrition }\end{array}$ & 78.5 & 42.0 & 60.25 & 82.0 \\
\hline $\begin{array}{c}\text { Mother's health and nutrition is } \\
\text { ensured }\end{array}$ & 68.5 & 70.5 & 69.5 & 53.5 \\
\hline \begin{tabular}{c} 
Others \\
\hline
\end{tabular} & 0 & 1.5 & 0.75 & 0 \\
\hline
\end{tabular}

Table 7: Percentage Distribution of Respondents by their Perception about Disadvantages of FP Methods: by area (Multiple Responses).

\begin{tabular}{|c|c|c|c|c|}
\hline \multirow{2}{*}{$\begin{array}{c}\text { Disadvantages of FP } \\
\text { methods }\end{array}$} & \multicolumn{3}{|c|}{ Intervention Areas } & $\begin{array}{c}\text { Control } \\
\text { Area }\end{array}$ \\
\cline { 2 - 5 } & Sylhet & Maulvibazar & Both & Habigonj \\
\hline Side effects & 90.0 & 94.0 & 92.0 & 71.5 \\
\hline Risk of infertility & 70.0 & 44.0 & 57.0 & 34.5 \\
\hline Husband does not want & 48.5 & 31.0 & 39.75 & 26.0 \\
\hline No disadvantage & 0.5 & 3.0 & 1.75 & 20.5 \\
\hline Others & 7.5 & 13.0 & 10.25 & 0.5 \\
\hline
\end{tabular}

Table 8: Percentage Distributions of Respondents According to their Opinion about Consequences of Frequent Pregnancies: by area (Multiple Responses).

\begin{tabular}{|c|c|c|c|c|}
\hline \multirow{2}{*}{$\begin{array}{c}\text { Consequences of frequent } \\
\text { pregnancies }\end{array}$} & \multicolumn{3}{|c|}{ Intervention Areas } & Control Area \\
\cline { 2 - 4 } & Sylhet & Maulvibazar & Both & Habigonj \\
\hline $\begin{array}{c}\text { Benefits of a large family } \\
\text { Leads to poor health of } \\
\text { mother and }\end{array}$ & 35.5 & 15.0 & 25.25 & 58.0 \\
\hline $\begin{array}{c}\text { children } \\
\text { Financial burden }\end{array}$ & 100.0 & 92.5 & 96.25 & 95.5 \\
\hline Inadequate birth spacing & 95.0 & 84.5 & 89.75 & 94.0 \\
\hline Others & 62.5 & 63.0 & 62.75 & 33.5 \\
\hline & 2.0 & 6.0 & 4 & 1.0 \\
\hline
\end{tabular}

Table 9: Percentage Distribution of the Female Respondents who have Knowledge about Different FP Methods: By Area.

\begin{tabular}{|c|c|c|c|c|}
\hline \multirow{2}{*}{ Methods of FP } & \multicolumn{3}{|c|}{ Intervention Areas } & Control Area \\
\cline { 2 - 5 } & $\begin{array}{c}\text { Sylhet } \\
\mathbf{n = 2 0 0}\end{array}$ & $\begin{array}{c}\text { Maulvibazar } \\
\mathbf{n = 2 0 0}\end{array}$ & $\begin{array}{c}\text { Both } \\
\mathbf{N = 4 0 0}\end{array}$ & $\begin{array}{c}\text { Habigonj } \\
\mathbf{N = 2 0 0}\end{array}$ \\
\hline Pill & 99.5 & 100.0 & 99.75 & 100.0 \\
\hline Emergency pill & 11.5 & 20.0 & 15.75 & 5.5 \\
\hline IUD/Copper T & 70.0 & 92.0 & 81 & 80.0 \\
\hline Injection & 98.5 & 99.5 & 99 & 97.0 \\
\hline Condom & 99.5 & 99.0 & 99.25 & 97.0 \\
\hline Implant/ Norplant & 79.5 & 96.0 & 87.75 & 88.0 \\
\hline Safe period & 67.5 & 67.5 & 67.5 & 38.5 \\
\hline Azol/withdrawal & 46.5 & 48.0 & 47.25 & 23.0 \\
\hline Ligation/ & 93.5 & 98.5 & 96 & 90.5 \\
\hline Tubectomy & 73.0 & 91.0 & 82 & 78.5 \\
\hline Vasectomy/NSV & 7.0 & & \\
\hline
\end{tabular}

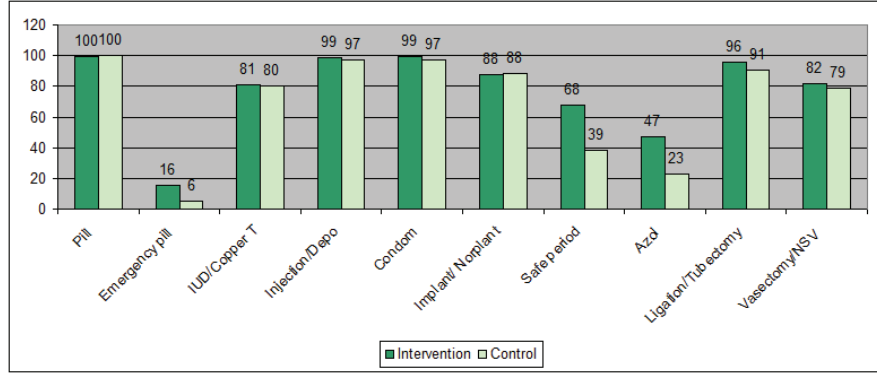

Figure 1: Percentage distribution of the women respondents who have knowledge about different FP methods by area.

Current use of family planning methods.

be quite high-this proportion in intervention area almost non-existent.

A further statistical analysis of the data points to the fact that the intervention did not influence the decision of neither male, nor female respondents to use family planning. However, the intervention did increase both male and female respondents' knowledge on several family planning methods. It appears that the female respondents benefitted from the intervention regarding their knowledge of the emergency pill, in safe period and azol/withdrawal. Furthermore, the intervention helped male respondents increasing their knowledge about implants, ligation and, again, safe periods. The male knowledge on vasectomy and IUD, however, decreased (Table 12).

\section{Ever use of FP methods}

Regarding past use of contraception, the respondents were asked whether they have ever used any contraceptive method 
and if yes, what methods they have used. The findings show that between 71 to 82 percent of the respondents have ever used any FP methods. The method-mix of ever users has more or less similar pattern like the current users. The pill was the most frequently used method (ranging between 70 to $78 \%$ ), followed by injection (ranging between $11 \%$ to $17 \%$ ), and condom. However, 3.5 percent women in control area were found to have ever used traditional method.The corresponding figure was nil for the intervention area (Tables 13,14).

\section{Consequences of not using family planning methods}

Respondents were asked about their perception regarding consequences of not using family planning method. The data shows that a vast majority of respondents in both the program and control areas are aware of the adverse effect of not using family planning method. Among the different responses, "economic burden" was mentioned by highest proportion (reported by 81 to $94 \%$ ), followed by "frequent pregnancies" (mentioned by 77 to $82 \%$ ) and "burden of large family" (reported by 55 to $77 \%$ ). There is no major difference in the perception of respondents in the two areas about the consequence of not using family planning (Table 15).

\section{Attitude towards abortion}

Women were asked about their perception regarding abortion. It was found that the proportion of women who considered abortion can be performed: 'if the health of a woman is at risk due to pregnancy', 'abortion as a sin' and 'abortion as a FP method' was considerably higher in control area than in intervention area (Figure 2).

\section{Management of unwanted pregnancy}

Although use of family planning method has been increasing continually, the cases of unwanted pregnancy is still high. Lack of knowledge on available family planning methods, ideal ways of using them and negative perception on use of

Table 10: Whether the Woman or Her Husband is Currently using Any FP Method: by area.

\begin{tabular}{|c|c|c|c|c|}
\hline \multirow{2}{*}{$\begin{array}{c}\text { Using any FP } \\
\text { methods }\end{array}$} & Sylhet & Maulvibazar & Both & Control Area \\
\cline { 2 - 5 } & Habigonj \\
\hline Yes & 75.0 & 58.5 & 66.75 & 66.0 \\
\hline No & 25.0 & 41.5 & 33.25 & 34.0 \\
\hline
\end{tabular}

Table 11: Percentage Distribution of Respondents according to their Current Use of FP: by Methods.

\begin{tabular}{|c|c|c|c|c|c|c|c|c|}
\hline \multirow{3}{*}{$\begin{array}{l}\text { Current use by } \\
\text { methods }\end{array}$} & \multicolumn{6}{|c|}{ Intervention Areas } & \multirow{2}{*}{\multicolumn{2}{|c|}{$\begin{array}{c}\text { Control Area } \\
\text { Habigonj } \\
\end{array}$}} \\
\hline & \multicolumn{2}{|c|}{ Sylhet } & \multicolumn{2}{|c|}{ Maulvibazar } & \multicolumn{2}{|c|}{ Both } & & \\
\hline & $n=150$ & $\%$ & $\mathrm{n}=\mathbf{1 1 7}$ & $\%$ & $N=267$ & $\%$ & $N=132$ & $\%$ \\
\hline Pill & 91 & 60.7 & 65 & 55.6 & 156 & 58.15 & 95 & 72.0 \\
\hline Condom & 5 & 3.3 & 11 & 9.4 & 16 & 6.35 & 6 & 4.5 \\
\hline Injection & 30 & 20.0 & 22 & 18.8 & 52 & 19.4 & 13 & 9.8 \\
\hline IUD/Copper T & 16 & 10.7 & 14 & 12.0 & 30 & 11.35 & 2 & 1.5 \\
\hline Implant/ Norplant & 0 & 0 & 1 & 0.9 & 1 & 0.45 & 0 & 0 \\
\hline $\begin{array}{l}\text { Traditional } \\
\text { method }\end{array}$ & 2 & 1.3 & 0 & 0 & 2 & 0.65 & 16 & 12.1 \\
\hline $\begin{array}{l}\text { Ligation/ } \\
\text { Vasectomy }\end{array}$ & 6 & 4.0 & 0 & 0 & 6 & 2 & 0 & 0 \\
\hline Other & 0 & 0 & 4 & 3.4 & 4 & 1.7 & 0 & 0 \\
\hline
\end{tabular}

Table 12: Whether Respondents (Both) are Currently using any Family Planning Methods? (Logit estimation ,1: Yes).

\begin{tabular}{|c|c|c|c|c|}
\hline Gender & \multicolumn{2}{|c|}{$\begin{array}{c}\text { Male Household } \\
\text { Heads }\end{array}$} & \multicolumn{3}{|c|}{ Female } \\
\hline Intervention & .06 & $(.08)$ & .04 & $(.06)$ \\
\hline Age & .00 & $(.00)$ & .01 & $(.00)$ \\
\hline Income & .00 & $(.00)$ & .00 & $(.00)$ \\
\hline Education & .01 & $(.01)$ & .01 & $(.01)$ \\
\hline Hindu & .06 & $(.09)$ & .07 & $(.06)$ \\
\hline Electricity & .14 & $(.09)$ & .05 & $(.06)$ \\
\hline Urban & .08 & $(.06)$ & .03 & $(.05)$ \\
\hline House owner & .10 & $(.07)$ & .06 & $(.05)$ \\
\hline Unqualified doctor & .00 & $(.07)$ & .00 & $(.05)$ \\
\hline UHC & .03 & $(.07)$ & -.04 & $(.05)$ \\
\hline FWC & .07 & $(.07)$ & .06 & $(.05)$ \\
\hline District Hospital & .03 & $(.08)$ & .03 & $(.05)$ \\
\hline
\end{tabular}

Occupation head household

\begin{tabular}{|c|c|c|c|c|}
\hline \multicolumn{5}{|l|}{ - Formal (base) } \\
\hline • Informal & .01 & $(.09)$ & -.01 & $(.05)$ \\
\hline - Agriculture & .21 & $(.12)$ & -.03 & $(.08)$ \\
\hline $\mathrm{N}$ & \multicolumn{2}{|c|}{269} & \multicolumn{2}{|r|}{545} \\
\hline Pseudo $\mathrm{R}^{2}$ & \multicolumn{2}{|c|}{.05} & \multicolumn{2}{|r|}{.03} \\
\hline Log likelihood & \multicolumn{2}{|c|}{-168.55} & \multicolumn{2}{|c|}{-331.41} \\
\hline
\end{tabular}

Logit estimation; average marginal effects. Standard errors presented in parentheses. ${ }^{*} p<.05 ;{ }^{* *} p<.01$

Table 13: Percentage Distribution of Women by Ever Use of FP Methods.

\begin{tabular}{c|c|c|c|c|c|c|c|c|} 
Whether & \multicolumn{4}{|c|}{ Intervention Areas } & \multicolumn{2}{c|}{ Control Area } \\
\cline { 2 - 9 } ever use any & \multicolumn{3}{|c|}{ Sylhet } & \multicolumn{2}{c|}{ Maulvibazar } & \multicolumn{2}{c|}{ Both } & \multicolumn{2}{c|}{ Habigonj } \\
\cline { 2 - 10 } Method & $\mathbf{n}$ & $\%$ & $\mathbf{n}$ & $\%$ & $\mathbf{N}$ & $\%$ & N & $\%$ \\
\hline Yes & 164 & 82.0 & 143 & 71.5 & 307 & 76.75 & 142 & 71.0 \\
\hline No & 36 & 18.0 & 57 & 28.5 & 93 & 23.25 & 58 & 29.0 \\
\hline
\end{tabular}

Table 14: Percentage Distribution of Women according to the Type of FP methods Ever used: By area.

\begin{tabular}{|l|c|c|c|c|c|c|c|c|}
\hline \multirow{2}{*}{$\begin{array}{l}\text { Types of FP } \\
\text { methods ever used }\end{array}$} & \multicolumn{7}{|c|}{ Intervention Areas } & \multicolumn{2}{c|}{ Control Area } \\
\cline { 2 - 10 } & \multicolumn{2}{|c|}{ Sylhet } & Maulvibazar & \multicolumn{2}{c|}{ Both } & \multicolumn{2}{c|}{ Habigonj } \\
\cline { 2 - 10 } & $\mathbf{n}$ & $\%$ & $\mathbf{n}$ & $\%$ & $\mathbf{N}$ & $\%$ & $\mathbf{N}$ & $\%$ \\
\hline Pill & 115 & 70.1 & 110 & 76.9 & 225 & 73.5 & 110 & 77.5 \\
\hline Condom & 15 & 9.1 & 9 & 6.3 & 24 & 7.7 & 8 & 5.6 \\
\hline Injection & 27 & 16.5 & 15 & 10.5 & 42 & 13.5 & 17 & 12.0 \\
\hline IUD/Copper T & 5 & 3.0 & 7 & 4.9 & 12 & 3.95 & 0 & 0 \\
\hline Implant/ Norplant & 0 & 0 & 2 & 1.4 & 2 & 0.7 & 2 & 1.4 \\
\hline Traditional method & 0 & 0 & 0 & 0 & 0 & 0 & 5 & 3.5 \\
\hline Ligation/ & 1 & 0.6 & 0 & 0 & 1 & 0.3 & 0 & 0 \\
\hline Tubectomy & 1 & 0.6 & 0 & 0 & 1 & 0.3 & 0 & 0 \\
\hline Others & & & & & & & & \\
\hline
\end{tabular}

family planning methods are some of the causes of unwanted pregnancy. Respondents were asked about their perception on different ways of termination of unwanted pregnancies. In the intervention area, $95.25 \%$ respondents mentioned MR as the way of pregnancy termination. By contrast, only 64 percent women in Habigonj said that they would go for MR in case of an unwanted pregnancy. The evidence suggests that a higher proportion of respondents in the intervention area are aware of modern and scientific method of unwanted pregnancy 
termination. The impact of the intervention is clearly visible in the sense that an overwhelming majority of respondents in the program area mentioned about MR to terminate an unwanted pregnancy. By contrast, about a quarter $(24 \%)$ of women in control area compared to only $5.5 \%$ in intervention area mentioned abortion to get rid of unwanted pregnancy, which has enormous health risk for women. Surprisingly, one- fourth (25\%) of the women in control area compared to $3.5 \%$ in intervention area (3\% in Sylhet and $4 \%$ in Maulvibazar) said that they would seek advice from Hekim/Kabiraj/Herbalist for the purpose. About a tenth of the (10.75\%) women in intervention area and a quarter of the (23.5\%) women in control area said that they would opt for homeopathy medicine to get rid of unwanted pregnancy. This implies that a sizeable proportion of respondents in the control area still prefer to go to herbalist or homeopathy medicine to terminate unwanted pregnancy (Tables 16-18).

\section{Knowledge about early marriage}

Respondents were asked whether they know about minimum age of marriage for girls and boys. In the intervention area, 76.5 and 36 percent of respondents know about minimum age of marriage for girls and boys respectively. However, a much lower proportion of women in control area (69.0\%) know about minimum age of marriage for girls and boys $(31.5 \%)$ respectively.

Respondents were asked about their perception regarding impact of early marriage on the girl. The various consequences mentioned by both program and control group women

Table 15: Percentage Distribution of Women according to their Perceptions about Consequences of not using Any FP Methods: By area.

\begin{tabular}{|c|c|c|c|c|}
\hline \multirow{2}{*}{ Consequences of not using FP } & \multicolumn{3}{|c|}{ Intervention Area } & Control Are \\
\cline { 2 - 5 } & Sylhet & Maulvibazar & Both & Habigonj \\
\hline $\begin{array}{c}\text { May conceive/frequent } \\
\text { pregnancies }\end{array}$ & 84.5 & 80.0 & 82.25 & 77.0 \\
\hline $\begin{array}{c}\text { Burden of large family/too many } \\
\text { children }\end{array}$ & 59.5 & 50.5 & 55 & 77.0 \\
\hline $\begin{array}{c}\text { Economic burden } \\
\text { Short spacing of birth }\end{array}$ & 86.5 & 75.5 & 81 & 93.5 \\
\hline $\begin{array}{c}\text { Poor health of mother and } \\
\text { children }\end{array}$ & 33.0 & 25.0 & 29.5 & 21.5 \\
\hline Don't know & 0 & 0 & 43.0 & 27.5 \\
\hline Others & 0 & 1.5 & 0.75 & 0 \\
\hline
\end{tabular}

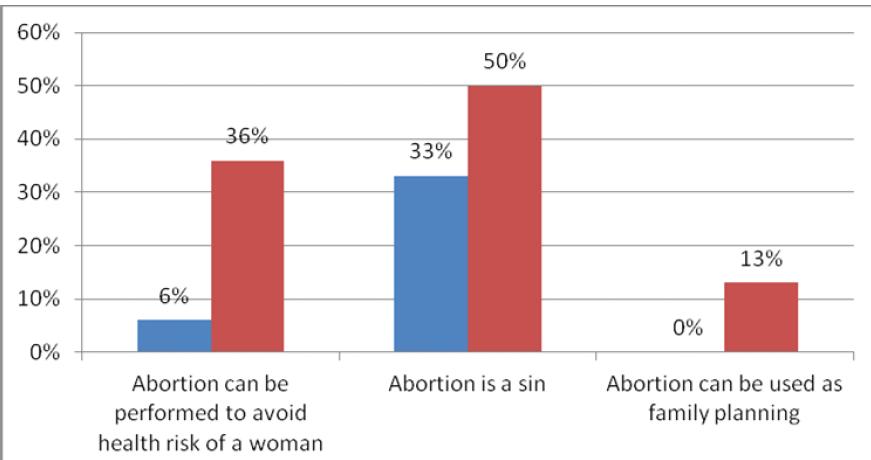

- Intervention Area Control Area

Figure 2: Percentage distributions of the respondents according to their opinion regarding abortion.
Table 16: Percentage Distribution of the Respondents according to their Perception on Management of Unwanted Pregnancy: by area (Multiple Response)

\begin{tabular}{|c|c|c|c|c|}
\hline \multirow{2}{*}{ Indicators } & \multicolumn{3}{|c|}{ Intervention Areas } & Control Area \\
\cline { 2 - 5 } & Sylhet & Maulvibazar & Both & Habigonj \\
\hline MR & 96.5 & 94.0 & 95.25 & 64.0 \\
\hline Abortion & 6.0 & 5.0 & 5.5 & 24.0 \\
\hline Taking advice from doctor & 91.5 & 76.5 & 84 & 45.0 \\
\hline Take herbal medicine & 3.0 & 4.0 & 3.5 & 25.0 \\
\hline DNC & 5.5 & 44.0 & 24.75 & 12.5 \\
\hline Homeopath treatment & 11.0 & 10.5 & 10.75 & 23.5 \\
\hline Do not know & 0.5 & 0 & 0.25 & 0.5 \\
\hline Others & 0.5 & 1.0 & 0.75 & 0 \\
\hline
\end{tabular}

Table 17: Respondents'(Both) perception on ways of termination/management of unwanted pregnancies(Logit estimation).

\begin{tabular}{|c|c|c|c|c|c|c|}
\hline Gender & \multicolumn{3}{|c|}{ Male } & \multicolumn{3}{|c|}{ Female } \\
\hline Intervention & .14 & $(.07)$ & * & .22 & $(.04)$ & ** \\
\hline Education & .00 & $(.01)$ & & .01 & $(.01)$ & \\
\hline Income & .00 & $(.00)$ & & .00 & $(.00)$ & \\
\hline Age & .00 & $(.00)$ & & .00 & $(.00)$ & * \\
\hline Hindu & .12 & $(.07)$ & & -.03 & $(.04)$ & \\
\hline Electricity & -.02 & $(.08)$ & & -.05 & $(.04)$ & \\
\hline Urban & -.09 & $(.05)$ & & .04 & (.03) & \\
\hline House owner & -.08 & $(.07)$ & & .01 & $(.04)$ & \\
\hline Unqualified doctor & -.14 & $(.06)$ & & -.04 & (.03) & \\
\hline UHC & -.06 & $(.06)$ & & .02 & $(.04)$ & \\
\hline FWC & .10 & $(.07)$ & & .03 & $(.04)$ & \\
\hline District Hospital & .02 & $(.07)$ & & .04 & $(.04)$ & \\
\hline \multicolumn{7}{|l|}{$\begin{array}{l}\text { Occupation head } \\
\text { household; }\end{array}$} \\
\hline \multicolumn{7}{|l|}{ - Formal (base) } \\
\hline - Informal & -.07 & $(.07)$ & & -.01 & $(.04)$ & \\
\hline - Agriculture & -.13 & $(.13)$ & & -.08 & $(.05)$ & \\
\hline $\mathrm{N}$ & \multicolumn{3}{|c|}{269} & \multicolumn{3}{|c|}{545} \\
\hline Pseudo $\mathrm{R}^{2}$ & \multicolumn{3}{|c|}{.14} & \multicolumn{3}{|c|}{.22} \\
\hline Log likelihood & \multicolumn{3}{|c|}{-138.48} & \multicolumn{3}{|c|}{-185.11} \\
\hline
\end{tabular}

are shown in Table-20 are more or less similar. The main consequences included "early pregnancy" (intervention area: 87 to $91.5 \%$; control area: $79 \%$ ), "adverse effect on health" (intervention: 78 to $81 \%$; control: $87.5 \%$ ),"can`t look after family properly" (intervention: 46 to 52\%; control: $37 \%$ ), and "can`t take proper care of children" (intervention: 24.5 to 28.5\%; control: 26.5\%) (Tables 19,20).

\section{Knowledge and Attitude towards Menstrual Regulation (MR)}

The women aged 15-49 were asked to respond on questions related to family planning methods and MR to explore their level of knowledge, attitude, beliefs, and perceptions about MR.

\section{Knowledge on MR}

Currently, MR is the most reliable (and govt. approved)

Citation: Islam Chowdhury SZ (2020) Practices and Attitudes of Women Regarding Family Planning And Menstrual Regulation in The Sylhet Division of Bangladesh. Glob J Infect Dis Clin Res 6(1): 014-028. DOI: https://doi.org/10.17352/2455-5363.000030 
Table 18: Perception of Both Respondents Whether Unmarried/married/widowed/divorced women have the right to terminate their unwanted pregnancies (Logit estimation, 1:yes).

\begin{tabular}{|c|c|c|c|c|c|c|c|c|c|c|c|c|}
\hline Gender & \multicolumn{3}{|c|}{ Male } & \multicolumn{9}{|c|}{ Female } \\
\hline Religion & \multicolumn{3}{|c|}{ All } & \multicolumn{3}{|c|}{ All } & \multicolumn{3}{|c|}{ Muslim } & \multicolumn{3}{|c|}{ Hindu } \\
\hline Intervention & .45 & $(.06)$ & $\star *$ & .19 & $(.05)$ & $\star \star$ & .14 & $(.05)$ & $\star *$ & .53 & (.13) & ** \\
\hline Education & -.01 & $(.01)$ & & .00 & $(.01)$ & & .00 & $(.01)$ & & .00 & $(.02)$ & \\
\hline Income & .00 & $(.00)$ & & .00 & $(.00)$ & & .00 & $(.00)$ & & .00 & $(.00)$ & \\
\hline Age & .00 & $(.00)$ & & .00 & $(.00)$ & & .00 & $(.00)$ & & .00 & $(.01)$ & \\
\hline Hindu & .12 & $(.08)$ & & -.16 & $(.05)$ & $\star *$ & & & & & & \\
\hline Electricity & -.02 & $(.08)$ & & .04 & $(.06)$ & & .03 & $(.06)$ & & .69 & $(.37)$ & \\
\hline Urban & -.04 & $(.05)$ & & .08 & $(.04)$ & & .13 & $(.04)$ & $\star \star$ & -.17 & $(.11)$ & \\
\hline House owner & -.02 & $(.07)$ & & .09 & $(.05)$ & & .06 & $(.05)$ & & .15 & $(.12)$ & \\
\hline Unqualified doctor & .21 & $(.07)$ & $\star *$ & -.07 & $(.04)$ & & -.06 & $(.04)$ & & -.20 & $(.10)$ & \\
\hline $\mathrm{UHC}$ & .08 & $(.07)$ & & -.04 & $(.05)$ & & -.05 & $(.05)$ & & -.38 & $(.19)$ & * \\
\hline FWC & -.04 & $(.07)$ & & .05 & $(.05)$ & & .05 & $(.05)$ & & .07 & $(.17)$ & \\
\hline District Hospital & .11 & $(.07)$ & & .01 & $(.05)$ & & .05 & $(.05)$ & & -.13 & $(.14)$ & \\
\hline \multicolumn{13}{|c|}{ Occupation head household; } \\
\hline \multicolumn{13}{|l|}{ - Formal (base) } \\
\hline - Informal & .01 & $(.07)$ & & -.04 & $(.05)$ & & -.14 & $(.05)$ & $\star *$ & .28 & $(.10)$ & ** \\
\hline - Agriculture & -.07 & $(.13)$ & & .01 & $(.07)$ & & -.06 & $(.06)$ & & .10 & $(.20)$ & \\
\hline $\mathrm{N}$ & \multicolumn{3}{|c|}{269} & \multicolumn{3}{|c|}{545} & \multicolumn{3}{|c|}{448} & \multicolumn{3}{|c|}{97} \\
\hline Pseudo $\mathrm{R}^{2}$ & \multicolumn{3}{|c|}{.20} & \multicolumn{3}{|c|}{.10} & \multicolumn{3}{|c|}{.07} & \multicolumn{3}{|c|}{.26} \\
\hline Log likelihood & \multicolumn{3}{|c|}{-138.90} & \multicolumn{3}{|c|}{-296.08} & \multicolumn{3}{|c|}{-231.41} & \multicolumn{3}{|c|}{-49.83} \\
\hline
\end{tabular}

Table 19: Percentage Distribution of the Women According to their Knowledge about Minimum Age of Marriage for Girls and Boys: By area.

\begin{tabular}{|c|c|c|c|c|c|c|c|c|}
\hline \multirow{2}{*}{ Indicators } & \multicolumn{4}{|c|}{ Intervention Areas } & \multicolumn{2}{c|}{ Control Area } \\
\cline { 2 - 11 } & \multicolumn{3}{|c|}{ Sylhet } & \multicolumn{1}{c|}{ Maulvibazar } & \multicolumn{2}{c|}{ Total } & \multicolumn{2}{c|}{ Habigonj } \\
\cline { 2 - 11 } & $\mathbf{n}$ & $\%$ & $\mathbf{n}$ & $\%$ & $\mathbf{N}$ & $\%$ & $\mathbf{N}$ & $\%$ \\
\hline $\begin{array}{c}\text { Know about minimum age } \\
\text { at marriage for girls }\end{array}$ & 176 & 88.0 & 130 & 65.0 & 306 & 76.5 & 138 & 69.0 \\
\hline $\begin{array}{c}\text { Know about minimum age } \\
\text { at marriage for boys }\end{array}$ & 87 & 43.5 & 57 & 28.5 & 144 & 36 & 63 & 31.5 \\
\hline
\end{tabular}

method to get rid of an unwanted pregnancy. Respondents were asked whether they have ever heard of MR. The responses are summarized in Table 21. It is evident that knowledge about MR is almost universal in the intervention area-all of the responding women in Sylhet $(99.5 \%)$ and Maulvibazar $(100 \%)$ have heard of MR. However, only $68 \%$ of the women in control area have ever heard of MR. This variation in awareness level between intervention and control area is in the expected direction because over the years, FPAB and MSCS have been trying to promote awareness regarding $M R$ in their program areas; and they have been highly successful in their endeavours.

\section{Timeline for MR}

According to government policy in Bangladesh, the MR procedure can be performed within eight weeks from the first day of last menstrual period (LMP) or within ten weeks from the first day of the LMP if performed by a trained medical doctor. The data shows that even though knowledge about MR is universal in the intervention area, women who have heard of MR not all of them know about the correct timeline for MR.
More than three-fourths of the women in the intervention area - $80.9 \%$ in Sylhet and $76.5 \%$ in Maulvibazar - possess the knowledge regarding the appropriate timing of performing MR. On the other hand, only half of the control group women who have heard of MR do have the correct knowledge (regarding timeline of MR) (Table 21,22).

\section{Assistance and service providers for MR}

Respondents were asked about their perception regarding the place where MR service is available, in the intervention area, or their knowledge on availability of service providers for MR in their locality. The data in Table 23 shows that in Sylhet, 77 per cent of respondents mentioned about FPAB followed by district hospital (64.8\%), FWC (62\%), UHC (60\%), MSCS (44\%), private clinic (33\%), MCWC (24.4\%) and other NGO clinics (24.4\%). In Maulvibazar, the pattern was more or less similar where the highest proportion mentioned about FWC (75.9\%) followed by Marie Stopes Clinic (68.4\%), DH (58.8\%) and UHC (58.8\%). In the control area, Habigonj, a lesser proportion of respondents mentioned about public facility/ skilled personnel ( 23 to $48 \%$ ), while a much higher proportion mentioned about traditional practitioners like kabiraj/hekim $(34.6 \%)$ or homeopathy medicine $(13.5 \%)$. However, because of the advocacy and awareness raising programme of FPAB and MSCS, a higher proportion of respondents in the intervention area possess the knowledge regarding skilled personnel who perform MR in their respective areas.

\section{Attitude towards MR}

Respondents were asked about their opinion on when one 
should go for performing MR. The various responses given by respondents include "poor parents with too many children should go for MR" (86.45\% in intervention and $69.1 \%$ in control area); "unwanted pregnancy should be terminated through MR" (76.95\% versus $84.6 \%$ ). Respondents also mentioned that "pregnancy at a very late stage of life should be terminated through MR" (32\% in intervention and $49 \%$ in control area)"; "If the health of the woman is at risk because of pregnancy then MR can be performed" (37\% in intervention and 32\% in control area). However, one-third of women in Habigonj (32.4\%) said that MR can be used as family planning, while only $1.75 \%$ of the respondents in intervention area mentioned MR as a method of family planning. This implies that only a very small minority of women in the intervention area have the wrong perception about MR, which clearly indicates the success of the MR intervention in the study area. However, a significant proportion of respondents consider MR as a sinthe fear of incurring the "curse of God". Such proportion was as high as $28 \%$ in the control area as compared to $10 \%$ in the intervention area (Table 24,25).

Table 20: Percentage Distributions of Women by their Perception About Impact/ Consequences of Early Marriage of Girls: By area.

\begin{tabular}{|c|c|c|c|c|c|c|c|c|}
\hline \multirow{3}{*}{$\begin{array}{l}\text { Consequences of early } \\
\text { marriage }\end{array}$} & \multicolumn{6}{|c|}{ Intervention Areas } & \multirow{2}{*}{\multicolumn{2}{|c|}{$\begin{array}{c}\text { Control Area } \\
\text { Habigonj } \\
\text { Habiganj }\end{array}$}} \\
\hline & \multicolumn{2}{|c|}{ Sylhet } & \multicolumn{2}{|c|}{ Maulvibazar } & \multicolumn{2}{|c|}{ Both } & & \\
\hline & $n$ & $\%$ & $\mathbf{n}$ & $\%$ & $\mathbf{N}$ & $\%$ & $\mathbf{N}$ & $\%$ \\
\hline Early pregnancy & 183 & 91.5 & 174 & 87.0 & 357 & 89.25 & 158 & 79.0 \\
\hline Adverse effect on health & 156 & 78.0 & 162 & 81.0 & 318 & 79.5 & 175 & 87.5 \\
\hline Break in education & 58 & 29.0 & 81 & 40.5 & 139 & 34.75 & 127 & 63.5 \\
\hline $\begin{array}{c}\text { Can't look after family } \\
\text { properly }\end{array}$ & 104 & 52.0 & 93 & 46.5 & 197 & 49.25 & 74 & 37.0 \\
\hline $\begin{array}{l}\text { Can't take proper care of } \\
\text { children }\end{array}$ & 57 & 28.5 & 49 & 24.5 & 106 & 26.5 & 53 & 26.5 \\
\hline $\begin{array}{l}\text { Can't adjust with husband } \\
\text { properly }\end{array}$ & 21 & 10.5 & 14 & 7.0 & 35 & 8.75 & 4 & 2.0 \\
\hline $\begin{array}{l}\text { More chances of violence } \\
\text { by husband }\end{array}$ & 3 & 1.5 & 4 & 2.0 & 7 & 1.75 & 2 & 1.0 \\
\hline No demerits & - & - & 3 & 1.5 & 3 & 0.75 & - & - \\
\hline Others & - & - & 1 & 0.5 & 1 & 0.25 & - & - \\
\hline
\end{tabular}

Table 21: Percentage distribution of the respondents according to their knowledge about MR.

\begin{tabular}{|c|c|c|c|c|}
\hline \multirow{2}{*}{$\begin{array}{c}\text { Ever heard } \\
\text { of MR }\end{array}$} & \multicolumn{3}{|c|}{ Intervention Areas } & Control Area \\
\cline { 2 - 5 } & Sylhet & Maulvibazar & Total & Habigonj \\
\hline Yes & 99.5 & 100 & 99.75 & 68.0 \\
\hline No & 0.5 & 0.0 & 0.25 & 32.0 \\
\hline N & 200 & 200 & 400 & 200 \\
\hline
\end{tabular}

Percentage distribution of the respondents according to their knowledge regarding the timeline of MR

\begin{tabular}{|c|c|c|c|c|c|c|c|c|}
\hline \multirow{3}{*}{ Indicators } & \multicolumn{4}{|c|}{ Intervention Areas } & \multirow{2}{*}{\multicolumn{2}{|c|}{$\begin{array}{c}\text { Intervention } \\
\text { Total } \\
\mathrm{N}=399\end{array}$}} & \multirow{2}{*}{\multicolumn{2}{|c|}{\begin{tabular}{|c|} 
Control Area \\
Habigonj \\
$\mathrm{N}=136$
\end{tabular}}} \\
\hline & \multicolumn{2}{|c|}{$\begin{array}{l}\text { Sylhet } \\
n=199\end{array}$} & \multicolumn{2}{|c|}{$\begin{array}{l}\text { Maulvibazar } \\
\qquad n=200\end{array}$} & & & & \\
\hline & $\mathrm{n}$ & $\%$ & $\mathrm{n}$ & $\%$ & $\mathrm{~N}$ & $\%$ & $\mathrm{~N}$ & $\%$ \\
\hline $\begin{array}{l}\text { Correct } \\
\text { knowledge } \\
\text { on the } \\
\text { timeline }\end{array}$ & 161 & 80.9 & 153 & 76.5 & 314 & 78.7 & 69 & 50.7 \\
\hline $\begin{array}{l}\text { Incorrect } \\
\text { knowledge } \\
\text { on the } \\
\text { timeline }\end{array}$ & 38 & 19.1 & 47 & 23.5 & 85 & 21.3 & 67 & 49.3 \\
\hline
\end{tabular}

Table 22: Knowledge Regarding MR(Both Respondents:Logistic Regression).

\begin{tabular}{|c|c|c|c|c|c|c|}
\hline Gender & \multicolumn{3}{|c|}{ Male } & \multicolumn{3}{|c|}{ Female } \\
\hline Intervention & .18 & $(.05)$ & ** & .16 & $(.04)$ & *夫 \\
\hline Education & .00 & $(.01)$ & & .00 & $(.00)$ & \\
\hline Income & .00 & $(.00)$ & & .00 & $(.00)$ & \\
\hline Age & .00 & $(.00)$ & & .00 & $(.00)$ & \\
\hline Hindu & .13 & $(.06)$ & * & -.01 & (.04) & \\
\hline Electricity & .02 & $(.06)$ & & .02 & (.04) & \\
\hline Urban & .05 & $(.04)$ & & .02 & (.03) & \\
\hline House owner & -.04 & $(.05)$ & & .08 & $(.03)$ & * \\
\hline Unqualified doctor & -.03 & $(.04)$ & & -.01 & (.03) & \\
\hline $\mathrm{UHC}$ & .10 & $(.05)$ & * & -.03 & (.03) & \\
\hline FWC & .02 & $(.05)$ & & .05 & $(.03)$ & \\
\hline District Hospital & .08 & $(.05)$ & & -.02 & $(.04)$ & \\
\hline \multicolumn{6}{|l|}{$\begin{array}{l}\text { Occupation head } \\
\text { household; }\end{array}$} & \\
\hline \multicolumn{7}{|l|}{ - Formal (base) } \\
\hline - Informal & -.02 & $(.05)$ & & .07 & $(.04)$ & \\
\hline - $\quad$ Agriculture & -.07 & $(.11)$ & & -.01 & $(.06)$ & \\
\hline $\mathrm{N}$ & \multicolumn{3}{|c|}{244} & \multicolumn{3}{|c|}{482} \\
\hline Pseudo $\mathrm{R}^{2}$ & \multicolumn{3}{|c|}{.23} & \multicolumn{3}{|c|}{.26} \\
\hline Log likelihood & \multicolumn{3}{|c|}{-68.45} & \multicolumn{3}{|c|}{-127.57} \\
\hline
\end{tabular}

Table 23: Percentage Distribution of Women according to their Knowledge on Availability of Service Providers for MR in their locality (by area).

\begin{tabular}{|c|c|c|c|c|c|c|c|c|}
\hline \multirow{2}{*}{$\begin{array}{l}\text { Whether know } \\
\text { about service } \\
\text { provider of MR }\end{array}$} & \multicolumn{6}{|c|}{ Intervention Areas } & \multirow{2}{*}{\multicolumn{2}{|c|}{$\begin{array}{c}\text { Control Area } \\
\text { Habigonj }\end{array}$}} \\
\hline & \multicolumn{2}{|c|}{ Sylhet } & \multicolumn{2}{|c|}{ Maulvibazar } & \multicolumn{2}{|c|}{ Both } & & \\
\hline Yes & \multicolumn{2}{|c|}{97.0} & \multicolumn{2}{|c|}{93.5} & \multicolumn{2}{|c|}{190.5} & \multicolumn{2}{|c|}{76.5} \\
\hline No & \multicolumn{2}{|c|}{3.0} & \multicolumn{2}{|c|}{6.5} & \multicolumn{2}{|c|}{9.5} & \multicolumn{2}{|c|}{23.5} \\
\hline \multirow[t]{2}{*}{$\mathrm{N}$} & & & & & & & & \\
\hline & \multicolumn{6}{|c|}{ Intervention Areas } & \multirow{2}{*}{\multicolumn{2}{|c|}{$\begin{array}{c}\text { Control Area } \\
\text { Habigonj } \\
(\mathrm{N}=104)\end{array}$}} \\
\hline \multirow{2}{*}{$\begin{array}{l}\text { Service provider/ } \\
\text { center }\end{array}$} & \multicolumn{2}{|c|}{$\begin{array}{l}\text { Sylhet } \\
(n=193)\end{array}$} & \multicolumn{2}{|c|}{$\begin{array}{c}\text { Maulvibazar } \\
\quad(n=187)\end{array}$} & \multicolumn{2}{|c|}{$\begin{array}{c}\text { Both } \\
(\mathrm{N}=380)\end{array}$} & & \\
\hline & No. & $\%$ & No. & $\%$ & No. & $\%$ & No. & $\%$ \\
\hline District hospital & 125 & 64.8 & 110 & 58.8 & 235 & 61.8 & 49 & 47.1 \\
\hline MCWC & 47 & 24.4 & 61 & 32.6 & 108 & 28.5 & 24 & 23.1 \\
\hline FWC & 120 & 62.2 & 142 & 75.9 & 262 & 69.05 & 50 & 48.1 \\
\hline UHC & 116 & 60.1 & 110 & 58.8 & 226 & 59.45 & 50 & 48.1 \\
\hline $\begin{array}{l}\text { Marie Stopes } \\
\text { Clinic }\end{array}$ & 85 & 44.0 & 128 & 68.4 & 213 & 56.2 & - & - \\
\hline Other NGO Clinics & 47 & 24.4 & 24 & 12.8 & 71 & 18.6 & 2 & 1.9 \\
\hline Private Clinic & 63 & 32.6 & 13 & 7.0 & 76 & 19.8 & 24 & 23.1 \\
\hline Medicine Seller & 1 & 0.5 & 2 & 1.1 & 3 & 0.8 & 2 & 1.9 \\
\hline Kabiraj/Hekim & 26 & 13.5 & 24 & 12.8 & 50 & 13.15 & 36 & 34.6 \\
\hline Homeopath & 3 & 1.6 & 10 & 5.3 & 13 & 3.45 & 14 & 13.5 \\
\hline Doctor/nurse & 26 & 13.5 & 7 & 3.7 & 33 & 8.6 & 28 & 26.9 \\
\hline Village doctor & - & - & - & - & - & - & 2 & 1.9 \\
\hline TBA/dai & 2 & 1.0 & - & - & 2 & 0.5 & 2 & 1.9 \\
\hline FPAB & 149 & 77.2 & - & - & 149 & 38.6 & - & - \\
\hline Pir/Fakir & - & - & - & - & - & - & 3 & 2.9 \\
\hline
\end{tabular}

\section{Whether MR is considered as a right of women?}

Respondents were asked whether they consider MR as a right of women to get rid of unwanted pregnancy. The findings show that four-fifths $(80 \%)$ of the women in the intervention area consider MR as a women`s right to terminate unwanted 
pregnancy. By contrast, only half of the control group women (52.5\%) have similar attitude towards MR. The findings imply that a much higher proportion of women are concerned about women`s rights and they have developed favourable attitude towards termination of unwanted pregnancy through MR compared to their counterparts in the control area.

Respondents were also asked about their opinion regarding abortion as a method of termination of pregnancy. Only $10 \%$ of the respondents in the intervention area with too many children were in support of abortion as a way of pregnancy termination for financial well-being. Only in case of pregnancy outside wedlock, a large majority of respondents in the intervention area were in support of abortion. The data shows that a vast majority of the respondents in the intervention area were against abortion irrespective of poverty of households or age at pregnancy, or on health grounds. The picture was quite different in the control area where most of the respondents mentioned that "poor parents with too many children" should go for abortion (57\%), "unwanted pregnancy" should be terminated through abortion (61.5\%). Respondents in control area also mentioned that pregnancy at a very late stage of life should be terminated through abortion (35.6\%), or if the health of the woman is at risk because of pregnancy then abortion can be performed (36.3\%). The findings imply that a vast majority of the women in the control area are not aware about the difference between "MR" and "abortion". Pregnancy termination through abortion is a risky procedure involving life threatening risks for women - including the risk of "dying" because of abortion. Unfortunately, a significant proportion of women in the control area are not aware of the health risk associated with abortion. More than a tenth of the control group women (12.6\%) still maintain that abortion can be used as a method of family planning. This needs immediate

Table 24: Percentage distribution of the respondents according to their opinion regarding MR issue.

\begin{tabular}{|c|c|c|c|c|c|c|c|c|}
\hline \multirow{3}{*}{$\begin{array}{l}\text { Opinion regarding reasons } \\
\text { for performing MR }\end{array}$} & \multicolumn{6}{|c|}{ Intervention Areas } & \multirow{2}{*}{\multicolumn{2}{|c|}{$\begin{array}{c}\text { Control Area } \\
\text { Habigonj } \\
(\mathrm{N}=136)\end{array}$}} \\
\hline & \multicolumn{2}{|c|}{$\begin{array}{l}\text { Sylhet } \\
(n=199)\end{array}$} & \multicolumn{2}{|c|}{$\begin{array}{c}\text { Maulvibazar } \\
(n=200)\end{array}$} & \multicolumn{2}{|c|}{$\begin{array}{c}\text { Both } \\
(\mathrm{N}=399)\end{array}$} & & \\
\hline & No. & $\%$ & No. & $\%$ & No. & $\%$ & No. & $\%$ \\
\hline $\begin{array}{l}\text { Poor parents with too many } \\
\text { children } \\
\text { should go for MR/For } \\
\text { financial well-being }\end{array}$ & 170 & 85.4 & 175 & 87.5 & 345 & 86.45 & 94 & 69.1 \\
\hline $\begin{array}{c}\text { Pregnancy at a very late stage } \\
\text { of life should be terminated } \\
\text { through MR }\end{array}$ & 74 & 37.2 & 55 & 27.5 & 129 & 32.35 & 67 & 49.3 \\
\hline $\begin{array}{l}\text { Pregnancy outside wedlock } \\
\text { should be } \\
\text { terminated through MR }\end{array}$ & 86 & 43.2 & 80 & 40.0 & 166 & 41.6 & 60 & 44.1 \\
\hline $\begin{array}{l}\text { Unwanted pregnancy should } \\
\text { be } \\
\text { terminated through MR }\end{array}$ & 163 & 81.9 & 144 & 72.0 & 307 & 76.95 & 115 & 84.6 \\
\hline $\begin{array}{l}\text { If the health of the woman is } \\
\text { at risk } \\
\text { because of pregnancy then } \\
\text { MR can be performed }\end{array}$ & 80 & 40.2 & 69 & 34.5 & 149 & 37.35 & 43 & 31.6 \\
\hline $\begin{array}{l}\text { Terminating pregnancy } \\
\text { through MR is a sin/against } \\
\text { religion }\end{array}$ & 19 & 9.5 & 22 & 11.0 & 41 & 10.25 & 38 & 27.9 \\
\hline $\begin{array}{c}\text { MR can be used as family } \\
\text { planning }\end{array}$ & 4 & 2.0 & 3 & 1.5 & 7 & 1.75 & 44 & 32.4 \\
\hline
\end{tabular}

Table 25: Whether Respondents Consider MR as a Right of Women: By Area.

\begin{tabular}{|c|c|c|c|c|}
\hline \multirow{2}{*}{ Indicators } & \multicolumn{3}{|c|}{ Intervention Areas } & Control Area \\
\cline { 2 - 5 } & Sylhet & Maulvibazar & Both & Habigonj \\
\hline Considers MR as a right & 82.5 & 79.0 & 80.75 & 52.5 \\
\hline $\begin{array}{c}\text { Do not considers MR as a } \\
\text { right }\end{array}$ & 17.5 & 21.0 & 19.25 & 47.5 \\
\hline
\end{tabular}

Table 26: Percentage Distribution of Women According to their Opinion Regarding Abortion.

\begin{tabular}{|c|c|c|c|c|c|c|c|c|}
\hline \multirow{3}{*}{$\begin{array}{l}\text { Opinion regarding } \\
\text { abortiona }\end{array}$} & \multicolumn{6}{|c|}{ Intervention Areas } & \multirow{2}{*}{\multicolumn{2}{|c|}{$\begin{array}{c}\text { Control Area } \\
\text { Habigonj } \\
(\mathrm{N}=135)\end{array}$}} \\
\hline & \multicolumn{2}{|c|}{$\begin{array}{c}\text { Sylhet } \\
(n=193)\end{array}$} & \multicolumn{2}{|c|}{$\begin{array}{c}\text { Maulvibazar } \\
(n=185)\end{array}$} & \multicolumn{2}{|c|}{$\begin{array}{c}\text { Both } \\
(\mathrm{N}=378)\end{array}$} & & \\
\hline & No. & $\%$ & No. & $\%$ & No. & $\%$ & No. & $\%$ \\
\hline $\begin{array}{l}\text { Poor parents with too } \\
\text { many children should go } \\
\text { for abortion/For financial } \\
\text { well- being }\end{array}$ & 18 & 9.3 & 21 & 11.4 & 39 & 10.35 & 77 & 57.0 \\
\hline $\begin{array}{c}\text { Pregnancy at a very } \\
\text { late stage of life should } \\
\text { be terminated through } \\
\text { abortion }\end{array}$ & 20 & 10.4 & 18 & 9.7 & 38 & 10.05 & 48 & 35.6 \\
\hline $\begin{array}{l}\text { Pregnancy outside wedlock } \\
\text { should be terminated } \\
\text { through abortion }\end{array}$ & 149 & 77.2 & 135 & 73.0 & 284 & 75.1 & 54 & 40.0 \\
\hline $\begin{array}{l}\text { Unwanted pregnancy } \\
\text { should be } \\
\text { terminated through } \\
\text { abortion }\end{array}$ & 15 & 7.8 & 13 & 7.0 & 28 & 7.4 & 83 & 61.5 \\
\hline $\begin{array}{l}\text { If the health of the woman } \\
\text { is at risk } \\
\text { because of pregnancy then } \\
\text { abortion can be performed }\end{array}$ & 12 & 6.2 & 9 & 4.9 & 21 & 5.55 & 49 & 36.3 \\
\hline $\begin{array}{l}\text { Terminating pregnancy } \\
\text { through abortion is a sin/ } \\
\text { against religion }\end{array}$ & 62 & 32.1 & 62 & 33.5 & 124 & 32.8 & 68 & 50.4 \\
\hline $\begin{array}{l}\text { Abortion can be used as } \\
\text { family planning }\end{array}$ & & & & & & & 17 & 12.6 \\
\hline
\end{tabular}

attention by planners and policy makers. It is also observed from the Table 26 that about a third $(32.8 \%)$ of the women in the intervention area and one-half $(50.4 \%)$ of the women in the control area are of the opinion that such an act is a great sin and would debar them from heaven.

\section{Experience of MR}

The respondents were also asked whether they know any MR clients - i.e. whether any of her relatives/friends had an MR, and if so at what stage of pregnancy the MR was performed. It is evident from Table 27 that a fourth of the respondents in intervention area $(23.3 \%)$ said that they personally know women who have undergone MR; while the corresponding proportion of such women was $43.9 \%$ in control area. Regarding the timeline when MR was performed, a much higher proportion of respondents in the intervention area maintain that MR was performed within 10 weeks from last day of menstrual period (LMP) $-83.25 \%$ in intervention area while less than two-thirds $(63.2 \%)$ of the MR cases in the control area was performed within the safe time limit of 10 weeks. Thus, according to the responses given by women, a sizeable proportion of MR cases in control area were performed after the expiry of prescribed timeline for safe MR. The proportion of unsafe MR cases was $12.75 \%$ in the intervention area, while the proportion of such cases was about three times higher $(36.8 \%)$

Citation: Islam Chowdhury SZ (2020) Practices and Attitudes of Women Regarding Family Planning And Menstrual Regulation in The Sylhet Division of Bangladesh. 
in control area. The findings suggest that in the intervention area, a larger proportion of MR was performed within the safe time period of 10 weeks from LMP compared to women from the control area. This is clearly an indication of the success of MR intervention in the study area in raising the awareness of people towards safe MR (Tables 28,29).

\section{Service providers for MR}

According to the government policy, safe MR needs to be performed either by a trained medical doctor (within 10 weeks from LMP) or by a trained paramedic/FWV (within 8 weeks). Judged on this criterion, a vast majority of MR cases in both the program areas were performed by skilled personnel-83.4\% in Sylhet and 75\% in Maulvibazar. However, the picture was not that much encouraging for the control area, only half of the MR cases (54\%) in Habigonj were attended by skilled personnel. Again, one-fourth $(26.3 \%)$ of MR cases in the control area was performed by unskilled professional (Kabiraj/herbalist/ homeopath etc.) compared to only $6.35 \%$ in the intervention area. This is really unfortunate that after 3 decades of MR program in Bangladesh, a sizeable proportion of MR clients in the control area sought help from traditional practitioners/herbalists or untrained providers to terminate their pregnancies. This issue deserves due attention by the program managers and policy makers, so that women stop going to unskilled provider for performing the MR.

\section{Complications faced after MR}

Respondents were asked whether they know of any complications their friends/relatives have suffered because of undergoing MR. Out of $179 \mathrm{MR}$ cases, $80 \mathrm{MR}$ clients (44.7\%) faced some complications after having an MR. However, there were major variations between the two areas in the proportion of MR clients who suffered complications after MR. The proportion ranged from $58 \%$ in Sylhet to $48 \%$ in Maulvibazar (intervention area), and to $36 \%$ in control area. Since a higher proportion of MR in the control area was performed

Table 27: Percentage Distribution of Women having Relatives/Friends who had experience of MR.

\begin{tabular}{|c|c|c|c|c|c|c|c|c|}
\hline \multirow{2}{*}{ Indicators } & \multicolumn{4}{|c|}{ Intervention Areas } & \multicolumn{2}{c|}{ Control Area } \\
\cline { 2 - 10 } & \multicolumn{2}{|c|}{ Sylhet } & \multicolumn{2}{|c|}{ Maulvibazar } & \multicolumn{2}{c|}{ Both } & \multicolumn{2}{c|}{ Habigonj } \\
\cline { 2 - 10 } & $\mathbf{n}$ & $\%$ & $\mathbf{n}$ & $\%$ & $\mathbf{N}$ & $\%$ & $\mathbf{N}$ & $\%$ \\
\hline Yes & 48 & 24.5 & 44 & 22.1 & 92 & 23.3 & 87 & 43.9 \\
\hline No & 148 & 75.5 & 155 & 77.9 & 303 & 76.7 & 111 & 56.1 \\
\hline
\end{tabular}

Table 28: Percentage Distribution of the Respondents According to the Timeline/ Duration of Pregnancy when their Relatives/Friends had the MR Performed.

\begin{tabular}{|c|c|c|c|c|c|c|c|c|}
\hline \multirow{3}{*}{$\begin{array}{l}\text { Duration of } \\
\text { pregnancy when } \\
\text { MR was performed }\end{array}$} & \multicolumn{6}{|c|}{ Intervention Areas } & \multirow{2}{*}{\multicolumn{2}{|c|}{$\begin{array}{c}\text { Control Area } \\
\text { (Habigonj) } \\
\text { Habiganj }\end{array}$}} \\
\hline & \multicolumn{2}{|c|}{ Sylhet } & \multicolumn{2}{|c|}{ Maulvibazar } & \multicolumn{2}{|c|}{ Both } & & \\
\hline & $\mathbf{n}$ & $\%$ & $\mathbf{n}$ & $\%$ & $\mathbf{N}$ & $\%$ & $\mathbf{N}$ & $\%$ \\
\hline 1-8 weeks & 34 & 70.8 & 18 & 40.9 & 52 & 61.4 & 43 & 49.4 \\
\hline 9-10 weeks & 8 & 16.7 & 19 & 43.2 & 27 & 21.85 & 12 & 13.8 \\
\hline $11-12$ weeks & 6 & 12.5 & 6 & 13.6 & 12 & 12.25 & 16 & 18.4 \\
\hline $12+$ weeks & 0 & 0.0 & 1 & 2.3 & 1 & 0.5 & 16 & 18.4 \\
\hline Overall & 48 & 100.0 & 44 & 100.0 & 92 & 96 & 87 & 100.0 \\
\hline Minimum & \multicolumn{2}{|c|}{2} & \multicolumn{2}{|c|}{2} & \multicolumn{2}{|c|}{2} & \multicolumn{2}{|c|}{4} \\
\hline Maximum & \multicolumn{2}{|c|}{12} & \multicolumn{2}{|c|}{14} & \multicolumn{2}{|c|}{13} & \multicolumn{2}{|c|}{24} \\
\hline
\end{tabular}

Table 29: Percentage Distribution of Women According to the Service Providers Who Performed MR for Their Relatives/Friends.

\begin{tabular}{|c|c|c|c|c|c|c|c|c|}
\hline \multirow[t]{3}{*}{ Service providers } & \multicolumn{6}{|c|}{ Intervention Areas } & \multirow{2}{*}{\multicolumn{2}{|c|}{$\begin{array}{c}\text { Control Area } \\
\text { (Habigonj) } \\
\text { Habiganj } \\
\end{array}$}} \\
\hline & \multicolumn{2}{|c|}{ Sylhet } & \multicolumn{2}{|c|}{ Maulvibazar } & \multicolumn{2}{|c|}{ Both } & & \\
\hline & $\mathbf{n}$ & $\%$ & $\mathbf{n}$ & $\%$ & $\mathbf{N}$ & $\%$ & $\mathbf{N}$ & $\%$ \\
\hline Skilled Doctor & 21 & 43.8 & 10 & 22.7 & 31 & 33.25 & 15 & 17.2 \\
\hline Nurse/Paramedic / FWV & 19 & 39.6 & 23 & 52.3 & 42 & 45.95 & 42 & 48.3 \\
\hline Public facility/NGO clinic & 5 & 10.4 & 7 & 15.9 & 12 & 13.15 & 7 & 8.0 \\
\hline $\begin{array}{c}\text { Kabiraz /Hekim/ } \\
\text { Herbalist }\end{array}$ & 2 & 4.2 & 2 & 4.5 & 4 & 4.35 & 21 & 24.1 \\
\hline Homeopath & 0 & 0.0 & 0 & 0.0 & 0 & 0 & 1 & 1.1 \\
\hline $\begin{array}{c}\text { Pharmacist /Village } \\
\text { doctor }\end{array}$ & 1 & 2.1 & 2 & 4.5 & 3 & 3.3 & 0 & 0.0 \\
\hline Other & 0 & 0.0 & 0 & 0.0 & 0 & 0 & 1 & 1.1 \\
\hline Total & 48 & 100.0 & 44 & 100.0 & 92 & 100 & 87 & 100.0 \\
\hline
\end{tabular}

by unskilled personnel (and also after the expiry of safe time period), it was expected that a higher proportion of MR clients would suffer from post MR complications in the control area. However, our results were in the opposite direction- a higher proportion of MR cases in the intervention area reportedly suffer from post-MR complications. This might be partly explained by the fact that a higher number of respondents in the control area are likely to have under-reported the incidence of post MR complications suffered by their friends/ relatives; or the probability of recall lapse was higher in case of control area respondents compared to their counterparts in the intervention area. The various complications mentioned by women from both intervention and control area include: 'excessive bleeding' (mentioned by around 54\% of program and $77 \%$ of control group of respondents), 'abdominal pain' reported by one-fifth of women $(21.45 \%)$ in the program area compared to $45 \%$ in control area (Table 30 ).

\section{Results of KIIs}

KIIs were conducted in order to complement the findings from the surveys. Key findings are:

- Awareness creation and mobilization program among the community people on safe timeline for MR, service providers for safe MR, VAW, and dements of early marriage through focus group discussion, courtyard discussion/meetings, film shows, etc. have contributed to the results obtained.

- The advocacy programs/seminar organized with government agencies, religious leaders, health professionals and community leaders, in order to recognize, protect and fulfill women's rights has also contributed to the results obtained.

- Adequate measures were taken for provision of post MR complications, post MR contraceptive services, creation of functional referral mechanism, and referral of high risk cases to higher level public/NGO facilities.

- All classes of people belonging to different age groups (adolescents, adults, and aged) and socio economic categories (rich/poor, educated/illiterate) get the relevant message regarding WHY, WHEN, WHERE, 
Table 30: Percentage Distribution of Women According to the Type of Complications faced by Their Relatives/Friends due to Unsafe MR.

\begin{tabular}{|c|c|c|c|c|c|c|c|c|}
\hline \multirow{3}{*}{ Complications } & \multicolumn{6}{|c|}{ Intervention Areas } & \multirow{2}{*}{\multicolumn{2}{|c|}{$\begin{array}{c}\text { Control Area } \\
\text { Habigonj }\end{array}$}} \\
\hline & \multicolumn{2}{|c|}{ Sylhet } & \multicolumn{2}{|c|}{ Maulvibazar } & \multicolumn{2}{|c|}{ Both } & & \\
\hline & $\mathrm{n}=\mathbf{2 8}$ & $\%$ & $n=21$ & $\%$ & $N=49$ & $\%$ & $\mathrm{~N}=31$ & $\%$ \\
\hline Excessive bleeding & 14 & 50.0 & 12 & 57.1 & 26 & 53.55 & 24 & 77.4 \\
\hline Senseless/Unconscious & 0 & 0.0 & 1 & 4.8 & 1 & 2.4 & 2 & 6.5 \\
\hline Vomiting & 1 & 3.6 & 1 & 4.8 & 2 & 4.2 & 0 & 0.0 \\
\hline $\begin{array}{l}\text { Abdominal pain/uterus } \\
\text { infection }\end{array}$ & 8 & 28.6 & 3 & 14.3 & 11 & 21.45 & 14 & 45.2 \\
\hline
\end{tabular}

and by WHOM the MR should be performed. This has contributed to increased mass awareness regarding FP and MR related issues.

- Women and male-heads have come out of religious dogma because of the intervention. Their mental horizon has broadened and now they understand better the importance of performing MR within the safe timeline and by skilled provider. Religious dogma/ superstitions among people regarding MR have been reduced. Their knowledge and awareness regarding the need for MR (and avoiding abortion) to terminate unwanted pregnancy has increased significantly. Moreover, their awareness regarding consequences of not using family planning and adverse impact of frequent pregnancies has increased tremendously.

\section{Conclusion}

The study was carried out in two intervention (Sylhet and Maulvibazar) and one control (Habiganj) areas. The study sample included 900 respondents- 600 women respondents aged 15-49 years and 300 male household heads. The sample was equally divided among the three areas-i.e 300 from each area (consisting of 200 women, 100 male-heads). The women were asked whether they have heard about different methods of family planning. the women in intervention areas were more aware of emergency pill, azolwithdrawal and safe period as compared to control area . Knowledge about timeline of MR is crucial for safe MR. The present study also assessed the knowledge of women based on their awareness on this timeline of MR. It was found that $51 \%$ of women had correct knowledge about the timeline of safe MR in control area, while the proportion was considerably higher in intervention areas (79\%). The intervention has been successful in improving female respondents' knowledge about the timeliness of MR, ceteris paribus. However, it appears that the intervention had a significantly stronger positive effect on the MR clients than on the female respondents. Education and age also seem to influence the knowledge of the female, while the male knowledge is associated with health seeking behavior. Knowledge on timeliness of the MR procedure and on appropriate service providers was significantly better in the intervention area than in the control area, pointing to a positive contribution of the project.

The intervention has been successful in improving both the MR clients' and female respondents' knowledge about the timeliness of MR, ceteris paribus. However, it appears that the intervention had a significantly stronger positive effect on the MR clients than on the female respondents. Education and age also seem to influence the knowledge of the female, while the male knowledge is associated with health seeking behavior. The findings indicate that both male and female respondents were more aware on MR in intervention areas as compared to control area. Women reported that early marriage and violence had reduced in the intervention area, though this could not be sustained by data from the surveys. Finally, women in the intervention area perceived that they received more respect and were more consulted regarding resolving crucial family situations. Women in the intervention area reported increase in self-worth, confidence and competence that they often translate into redefining social customs and rituals for themselves and their children. Women from poor households and marginalized communities now can have easy access to $\mathrm{RH}$ services including access to safe MR. Women also have gained positively in their ability to seek help from skilled provider in case of unwanted pregnancy.

\section{References}

1. Ali MS, Zahir M, Hasan KM (1978) Report on legal aspects of population planning, Bangladesh. Dhaka: The BangladesI Institute of Law and International Affairs.

2. Akhter H (1988) Abortion in Bangladesh, in: Sachdev $P$, ed., International Handbook on Abortion, New York: Greenwood Press, 1988.

3. Dixon-Mueller (1988) Assessing Women's Economic Contributions to Development", International Labour Office 92

4. Tietz R (1975) An experimental analysis in wage bargaining behavior. Journal of Institutional and Economics 131: 44-91. Link: https://bit.ly/3cLulwA

5. Government of the People's Republic of Bangladesh (1979) Memo No. 5-14/MCH-FP/Trg.79, Dhaka, Bangladesh: Population Control and Family Planning Division

6. World Bank (2009) Developing partnerships: Gender, sexuality, and the reformed World Bank. University of Minnesota Press 328. Link: https://bit.ly/2ACDdWX

7. NIPORT (2011) Bangladesh Maternal Mortality and Health Care Survey 2010 Summary of Key Findings and Implications, Dhaka, Bangladesh: NIPORT. Link: https://bit.ly/36fvObN

8. UNDP/GoB (2009) The nexus between urban poverty and local environmental degradation of Rajshahi City. The International Journal of Environmental Cultural, Economic and Sustainability 5: 229-240. Link: https://bit.ly/2WN97sp

9. WHO (2012) Global, regional, and national causes of child mortality: an updated systematic analysis for 2010 with time trends since 2000 .

10. Hossain A, Maddow-Zimet I, Singh S, Remez L (2012) Menstrual regulation, unsafe abortion and maternal health in Bangladesh, In Brief, New York Guttmacher Institute 3. Link: https://bit.ly/2X9gbP8

11. Rochat RW, Jabeen S, Rosenberg MJ, Measham AR, Khan AR, et al. (1981) Maternal and abortion related deaths in Bangladesh 1978-79. Int J Gynaecol Obstet 19: 155-164. Link: https://bit.ly/2zhHqPs

12. Blanchet T, Fauveau V (1989) Deaths from injuries, and induced abortion among rural Bangladeshi women. Social Science and Medicine 29: 11211127. Link: https://bit.ly/3g5LW4a

13. NIPORT (2001) Bangladesh Health and Demographic Survey 1999-2000. National Institute of Population Research and Training (NIPORT). Link: https://bit.ly/3cZi3k0 
14. NIPORT (2003) Bangladesh Maternal Health Services and Maternal Mortality Survey, 2001. Dhaka, Bangladesh: National Institute of Population Research and Training (NIPORT) (2003). Macro, O. R. C., and Johns Hopkins.

15. Syeda Firoza B, Kamal H, Tahera Khanam S, Kamal GM (1985) Evaluation of MR services and training pro- grams. Dhaka: BAPSA.

16. Adrienne G (1985) Menstrual regulation and induced abortion in Bangladesh. Memo to Oscar Harkavy, the Ford Foundation, New York.

17. Akhter $H(2001)$ Midlevel provider in menstrual regulation, Bangladesh experience, paper presented at the conference Expanding Access: Advancing the Roles of Midlevel Proveders in Menstrual Regulation and Elective Abortion Care, South Africa.

18. Akhter $\mathrm{H}$ (2001) Currentst at us and access to abortion: the Bangladesh experience. in: Klugman B and Budlender D, eds., Advocating for Abortion Access: Eleven Country Studies, Johannesburg, South Africa: Women's Health Project, School of Public Health, University of the Witwatersrand, 2001.

19. NIPORT (2009) Mitra and Associates and Macro International, Bangladesh Demographic and Health Survey, 2007, Dhaka, Bangladesh and Calverton, MD, USA: NIPORT, Mitra and Associates, Macro International.

20. Johnston H (2011) Scaledup and marginalized: are view of Bangladesh's menstrual regulation programme and its impact, in: Blas E, Sommerfeld J and Karup A, eds., Social Determinants Approachesto Public Health: From Concept to Practice, Geneva: World Health Organization 9-24.

21. Chowdhury SN, Moni DA (2004) situation analysis of the menstrual regulation programme in Bangladesh. Reprod Health Matters 12: 95-104. Link: https://bit.ly/2zROTGL

22. Singh S, Wulf D, Jones H (1997) Estimating the Level of Abortion in the Philippines and Bangladesh. Int Fam Plan Perspect 23: 100-107. Link: https://bit.ly/2Zr8XJf

23. Johnston H, Oliveras E, Akhter S, Walker DG (2010) Health system costs of menstrual regulation and care for abortion complications in Bangladesh. Int Perspect Sex Reprod Health 36: 197-204. Link: https://bit.ly/3e1inir

24. (2004) MR services performance statistics, in: Health and Rights, Dhaka: Bangladesh, Sexual and Reproductive Health and Rights (SRHR) Consortium 4 .

25. Rashid S, Akram $O$ and Standing $H$ (2011) The sexual and reproductive health care market in Bangladesh: where do poor women go? 19: 21-31. Link: https://bit.ly/2LIpzUv

26. Rashid SF (2010) Quality of care and pregnancy terminations for adolescent women in urban slums, Bangladesh. Link: https://bit.ly/3e03ZqK

27. UNFPA (2007) Annual Report UNFPA 2006. Link: https://bit.ly/3bNOLnp

\section{Discover a bigger Impact and Visibility of your article publication with}

\section{Peertechz Publications}

Highlights

* Signatory publisher of ORCID

* Signatory Publisher of DORA (San Francisco Declaration on Research Assessment)

* Articles archived in worlds' renowned service providers such as Portico, CNKI, AGRIS, TDNet, Base (Bielefeld University Library), CrossRef, Scilit, J-Gate etc.

* Journals indexed in ICMJE, SHERPA/ROMEO, Google Scholar etc.

- OAI-PMH (Open Archives Initiative Protocol for Metadata Harvesting)

* Dedicated Editorial Board for every journa

* Accurate and rapid peer-review process

* Increased citations of published articles through promotions

* Reduced timeline for article publication

Submit your articles and experience a new surge in publication services (https://www.peertechz.com/submission).

Peertechz journals wishes everlasting success in your every endeavours.

Copyright: @ 2020 Islam Chowdhury SZ. This is an open-access article distributed under the terms of the Creative Commons Attribution License, which permits unrestricted use, distribution, and reproduction in any medium, provided the original author and source are credited.

Citation: Islam Chowdhury SZ (2020) Practices and Attitudes of Women Regarding Family Planning And Menstrual Regulation in The Sylhet Division of Bangladesh. Glob J Infect Dis Clin Res 6(1): 014-028. DOI: https://doi.org/10.17352/2455-5363.000030 